\title{
Resistances: Austen and Wedderburn
}

With the novel circulating more widely in the public sphere, there was growing concern that these texts could instil "dangerous" ideas in the minds of "impressionable" women and servants. Whereas eighteenthcentury writing conventions foregrounded modesty and the display of piousness, the nineteenth century presents readers with more complex characters that are sometimes hardly sympathetic. In this chapter I juxtapose the most famous writer of (female) affective individualism, Jane Austen, and her canonical third published novel Mansfield Park that features her supposedly most unpopular heroine Fanny Price with orator Robert Wedderburn's much more obscure pamphlet The Horrors of Slavery. ${ }^{1}$ In their texts there is not as much thematic or generic overlap as in Defoe and Equiano and there is also no direct intertextuality as in Sancho and Sterne. Nevertheless, I suggest that by "entangling" their voices as well we get a better understanding of how writers used the affective means of prose writing to introduce more resistant tonalities of familial feeling. Austen presents wilful female subjectivity in a family that invested in slavery and Wedderburn the unruly planter son claims familiarity with both his enslaved mother and his slave-owning father, challenging the formula of the "horrors of slavery". Via internal focalization and incendiary rhetoric respectively both texts tonally also create a more intimate familiarity with their readers. They thus aesthetically resist writing conventions and introduce more ambivalent nuance: pushing the limits of the genre of the country-house novel in Austen and refuting the demure

(C) The Author(s) 2021

E. Haschemi Yekani, Familial Feeling, https://doi.org/10.1007/978-3-030-58641-6_4 
tone of abolitionist writing in Wedderburn. These aesthetic resistances are closely linked to the texts' discussions of the political status of women and free people of colour. Rather than rehash the analogy of women on the marriage market as slaves, I suggest an entangled perspective on how both authors use writing as a tool for resisting the interdependent rather than separate normative orders of gender and race which were being renegotiated on a global scale in the early nineteenth century.

This is a period of transitions both in international colonial and domestic familial terms. Following the 1807 abolition of the slave trade, the system and realities of slavery did not vanish overnight; and so, while there seems to be a general British public consensus in favour of gradual emancipation, the steps this might involve were controversial since there was justified widespread fear of insurgence in the Caribbean (cf. Perry 1994 for especial focus on Haiti; see also Lowe 2015: 23). ${ }^{2}$ At the same time, the social shifts described in the introduction paved the way for the affective ideal of familial belonging which by now is engrained in the more established novel form that departs from conventionalised sentimentalism and centres on domesticity idealising bourgeois femininity. With growing fears about Britain's future standing in the colonies, the family is consolidated once more as the arena of social cohesion at home. Both The Horrors of Slavery and Mansfield Park mark a shift from the old plantation system based on British absentee planters and enslaved labour to an imperial reformation of British colonialism as a new form of imperial capitalism. ${ }^{3}$

By joining Austen and Wedderburn in this chapter, I thus want to question how familial feeling is played out as a governing principle that is paradoxically both increasingly normalised and contested in early nineteenth-century writing. No longer needing to establish individualism and the conventions of formal realism, as in Defoe, or, a claiming of subject status, as is Equiano, nor engaging in the witty conversation of sentimental men of letters, such as Sterne and Sancho, Austen and Wedderburn provide representations of family life that concern the everyday in Britain and its entanglements with settings abroad in the Caribbean. Both become chroniclers of affective responses to this new familiarity in writing (that also seems to invite more personal responses from readers), granted in very different formal registers. Wedderburn plagiarises formulaic abolitionist writing and at the same time, in true anarchical fashion, challenges the status quo of gendered and racialised familial hierarchies by demanding his inclusion into the realm of familial feeling, calling out his slaveowning Scottish father. Austen, in turn, introduces the introspection of 
women on the "marriage market" in her famous style of free indirect discourse. This blurring of narrative perspective, wavering between the voice of the narrator and the focalization of the characters, has led to a vivid debate regarding her usage of irony and satire. ${ }^{4}$ To be clear then, employing the term "resistances" to describe the tonality of these two authors' texts is not meant as a straightforward political evaluation of their opinions regarding slavery or British imperialism. Rather, I read Austen and Wedderburn's writing styles as introducing both aesthetic and thereby by extension, of course, also political, wedges into the family romance that are more ambivalent than the subversive versus conservative binary might suggest. In contrast to the idea of counterpoint, proposed by Edward Said in his landmark reading of Austen's novel that I will revisit in this chapter, I want to use the lens of entangled histories to show that slavery was, in fact, quite central to the world of metropolitan polite discourse rather than the often-assumed taboo that delicate society could not mention. Such an entangled view also resists a clear-cut spatial binary of the colonies versus the metropole and links questions of class and the new imperial and gendered ordering of Britain's affective make-up.

\section{The Will to Feel: Jane Austen's Mansfield Park}

Published in 1814, Mansfield Park's plot either takes place directly preceding or following the abolition of the slave trade in $1807 . .^{5}$ The novel recounts how class mobility coincides with a new form of familial emotionality and belonging. ${ }^{6}$ Said rests his famous analysis of the text on the premise that in Austen's "pre-imperialist novel" blood relation is no longer sufficient to uphold the continuity of familial heritage. What emerges instead is a "pattern of affiliation" (1994: 84-85). As is well-known, the imprudent choice of marriage that separates the three Ward sisters, who become Lady Bertram, Mrs Norris, and Mrs Price respectively, is the outset of this economic family drama. Mrs Price is forced by circumstance to appeal to her estranged sister and her rich husband. ${ }^{7}$ Initially, she hopes to situate her oldest son on Sir Thomas's West Indian property or even send him "to the East" (MP 7). The British system of primogeniture and the reliance on a "good match" for women gradually creates class discrepancies even within families - with the smaller nuclear family becoming the main pecuniary household unit. "Children of the same parents could be divided into different classes, and within a few generations, their connections to each other might be completely effaced" (Stewart 1993: 88). On 
the one hand, women gain more say in their choice of spouse with the conception of marriage as based on affective ties and, on the other hand, it is specifically the lower gentry that comes under pressure to secure the financial means of their younger sons and daughters. Spinsters and bachelors who cannot find a suitable match enter the demeaning profession of the governess or try to bypass these financial limitations by emigrating to the colonies; and it is their plights that become the plots of popular nineteenth-century fiction.

In Austen's novel, the fate of upward-class mobility initially falls on the little girl Fanny instead of her brother William. Having no children herself and always acting in her own best financial interest, Mrs Norris appeals on her niece's behalf by asking Sir Thomas, "Is not she a sister's child" (MP 9), almost echoing the famous abolitionist slogan "Am I not A Man/ Woman and a Brother/Sister". Deirdre Coleman (2009) understands this as satirising the very inequality that the supposed sibling bond between Black and white in abolitionist propaganda did not question. Rather than accepting Fanny into the family unconditionally, it is social etiquette and hierarchies that need stabilising. The introduction of the new uncouth family member is discussed as a risky endeavour, as it might not promise the refinement of the lower-class relation but the corruption of the four Bertram children. Given the age difference, however, Lady and Sir Bertram rest somewhat assured that their older children might withstand a potential erosion of manners (cf. MP 11).

On first meeting her, the ten-year-old plain Fanny does not immediately "disgust" (MP 13) the family. The social reform of a distant lowerclass family member is described in terms of specific settings, most notably Mansfield Park itself. Fanny's feeling of being out of place is enhanced by the sheer size of the surroundings. "The grandeur of the house astonished but could not console her. The rooms were too large for her to move in with ease; whatever she touched she expected to injure, and she crept about in constant terror of something or other; often retreating towards her own chamber to cry" (MP 15). Overwhelmed by her new home and stunned by the demands of affective individualism that her class mobility entails, her lacking expression of the right kind of enthusiastic emotionality- "a wicked thing for her not to be happy"-is interpreted as sulkiness by Mrs Norris (MP 14). The heterodiegetic narrator, too, repeatedly comments on the discrepancy between expected feeling and Fanny's perceived ungratefulness. She only settles in once the younger son Edmund, who is planning to enter the clergy as was common for second-born sons, 
becomes her friend. He also helps Fanny keep in touch with her other male confidante, her older brother William, who is invited to visit Mansfield Park before embarking on a career as a sailor.

With the death of Mr Norris and the poor returns from the Antiguan estate five years later (which corresponds to the actual decline of the sugar trade in Antigua at the time), there is some disruption in the familial framework. Fanny is transplanted from Mansfield Park to the new abode of Mrs Norris, and Sir Thomas is obliged to travel abroad together with his eldest and wasteful son, Tom, leading to their subsequent absence of two years. The financial and family difficulties need to be resolved at home and in Antigua linking the domestic and the colonial spheres which brings me back to Said's famous assessment of the novel. Said is highly critical of the imbalance that Austen bestows on Antigua and England as geographical settings in the text and reads Fanny as complicit with her slave-owning uncle. However, it is interesting that while Said mentions Mansfield Park's status as "pre-imperialist", he does not really enquire into its status as "post-abolition". Consequently, despite critiquing Austen for her neglect of Antigua as a setting, Said himself spends little time in reviewing the debate on the abolition of the slave trade and its aftermath in Britain in the fictional present of the novel (cf. Boulukos 2006: 366).

Unsurprisingly, there was a boom in postcolonial readings of Mansfield Park in the wake of Said's Culture and Imperialism in the second half of the 1990s (cf. Wood 2002: 298). It is worth noting that in the subsequent postcolonial and equally prevalent feminist debates there is a permanent conflation of the author Austen with her narrator or one of the protagonists and their supposed endorsement of slavery or its abolition. There are also disputes about misquoting individual characters, as in the famous silence surrounding slavery in Mansfield Park to which I will return. Said himself evidently struggled with a desire for a simultaneous literary "absolution" and a postcolonial reprobation of Austen's political views. Trying to avoid a banal "rhetoric of blame" (1994: 96), Said wants to be able to call out Austen on her politics and celebrate her as part of the "great tradition". ${ }^{8}$ Said is, of course, correct in highlighting that the restricted English world of Austen's Mansfield Park knows no Black agency as embodied by Wedderburn. But this does not quite amount to unquestioned male authority. ${ }^{9}$ To state that the colonial and the domestic sphere are entangled then is not to argue that they are equally represented in works of fiction, and strikingly, the familial feeling in Austen does not extend into the colonies. As Boulukos (2006: 366) persuasively points out, the most 
problematic aspect in Said's framing is not that he challenges the lack of representation of Antigua as a setting but the idea that a critique of slavery is an anachronistic demand of postcolonial scholars today when, in fact, the debate on the abolition of slavery is contemporary to Austen. ${ }^{10}$ Ambivalence is not something the critic retrospectively needs to attach to the politics of the author; it is already present in the text.

As the first of two female authors covered in this study after all, Austen's writing has been repeatedly discussed in relation to the historical coincidence of the emancipation of the enslaved and the "woman question" linking her to early feminist voices like Mary Wollstonecraft, but also to more conservative Evangelical abolitionists like Hannah More. Accordingly, within the ensuing critical debate, the politics of feminism and abolition are conflictingly related. In contrast to Margaret Kirkham's emphasis on Austen's political radicalism, for example, in her Jane Austen, Feminism and Fiction (1997), more recent postcolonial scholarship addresses her collusion again, ${ }^{11}$ while also being critical of Said's oversights. ${ }^{12}$ On the whole Austen criticism itself has become a battlefield of poststructuralist versus more traditional schools of literary interpretation. ${ }^{13}$ Now, more than thirty years after Said's reading was first published, ${ }^{14}$ there also seems to be a worrying incipient backlash against both feminist and postcolonial literary criticism, especially regarding the significance attributed to the topic of enslavement.

Austen's familiarity with the issue is well-established given her praise of Thomas Clarkson's History of the Abolition of the Slave Trade (1808) in a letter to her sister Cassandra (cf. Smith 1994: 212; Wiley 2014: 63; Wiltshire 2003: 311). ${ }^{15}$ In Clarkson's abolitionist text, plantocrat John Norris is condemned for his misdeeds. Consequently, one can construe a link of names not only between Lord Mansfield and Mansfield Park, ${ }^{16}$ but also between the detested slave owner and aunt Norris (cf. Ferguson 1991: 121; Kelly 2008: 178). ${ }^{17}$ Additionally, Moira Ferguson has pointed out that Mansfield Park itself is even described as a plantation in the text (cf. MP 52; Ferguson 1991: 130). Hence, the setting Mansfield Park is palimpsestically linked to West Indian slavery rather than its blissful domestic counterpart, as which Said describes it. David Bartine and Eileen Maguire (2009: 35) make a similar point in offering a complex reevaluation of Said's model of counterpoint, which transfers the musical capacity to juxtapose two different themes that are uttered simultaneously to literary readings. They distinguish tonal and dissonant counterpoint to highlight that counterpoint cannot only produce harmony (as Said argues). 
While the tonal model of counterpoint would emphasise consonance or harmony, linked to the image of the home in literature, the atonal or dissonant mode would include tension suggesting the image of a "dissonated" home (Bartine and Maguire 2009: 39). ${ }^{18}$

So, to be clear, the main concern in the following is not the dispute whether Austen, the real-life person and author, was "proto-feminist" or a moralising conservative (cf. Butler 1987), whether she was opposed to the slave trade or supported British imperial ambitions (or, in this case, both, which I am inclined to believe). Rather I want to understand how familial feeling is constructed in the novel in relation to Britain's role as an increasingly imperial rather than slave-holding nation. To this end, it is certainly apposite to demand close attention to the textual make-up of the source and how it addresses the coincidence of the qualms about the role of women and the status of formerly enslaved human beings. These developments shape the emotionally expanding vocabulary of the novel in the nineteenth century, in general, and Austen's Mansfield Park, in particular. In clear contrast to John Wiltshire then, who in a reductive and frankly hostile remark, claims "Postcolonial criticism, in fact, has colonised Mansfield Park" (2003: 303), I believe it pertinent to engage with, rather than dismiss earlier postcolonial and feminist analyses of a canonical text that relies on silences and allusions. Wiltshire argues that associations of Mansfield Park with Lord Mansfield and Mrs Norris with the planter Norris are far-fetched ideologically inclined readings. He also questions whether the financial dependence on the Antiguan plantation is given undue credit by postcolonial critics ${ }^{19}$ - but most of all, he contests the validity of analyses that claim an analogous relationship between the marriage market and/or governess trade and the slave trade-given the fact that (middle-class white) women were increasingly able to resist being married off against their will, as is evident in Mansfield Park. While I strongly disagree with what comes across as a conservative anti-feminist and anti-postcolonial "rescue" of the "true" Austen, ${ }^{20} \mathrm{I}$ do believe Wiltshire has a point in emphasising the limits of the problematic analogy of women's status as "slaves" within patriarchal family constellations. ${ }^{21}$ Not only does such a framing ignore the gender of enslaved women and men, it also plays down white women's agency within colonial power relations, as has been widely noted. Fraiman, for instance, writes about Austen, "The imperialist gesture is to exploit the symbolic value of slavery, while ignoring slaves as suffering and resistant historical subjects" (1995: 813). 
To do justice to these interdependent processes of Othering, I propose a more nuanced reading of Fanny's expressions of familial feeling that places greater emphasis on the representation of emotional ambivalence in the actual text, which I call her "will to feel" that is shaped by a new form of realistic introspection and uncertainty regarding expected emotionality. With this approach, I follow Janet Todd, who critically discusses and departs from earlier feminist attempts of identifying Austen either with conservative or progressive politics in the wake of the French Revolution and the debate on women's rights. She suggests a different approach, namely focusing on Austen's aesthetic rejection of the cult of sensibility. Todd argues that the "main motivator of Austen, beyond any party political purpose, is her opposition to sensibility in all its forms, whether it be romantic fantasy in young girls, spontaneous feminine understanding or intuition, political aspirations or plot expectations" (1991: 76). Nevertheless, this aesthetic rejection of sentimentalism and the associated infantilising of women as well as the depiction of the emotional maturing of Fanny in Mansfield Park is not happening in a political vacuum. It is clearly entangled with the debate on and the aftermath of the abolition of the slave trade.

When Fanny, her cousin Maria Bertram, who is engaged to be married to the prudent but boring Mr Rushworth, and Henry Crawford are stuck behind a locked gate on a walk on Rushworth's vast estate Sotherton, Maria is eager to bypass the obstacle without waiting for her fiancé's return with the key. Fanny believes this to be an unwise decision as Maria's prospects seem felicitously settled in contrast to her own. Nonetheless, in the ensuing conversation, in which Henry Crawford seduces Maria into bypassing the gate and, by extension, codes of proper feminine conduct, the starling of Laurence Sterne's Sentimental Journey reappears as an intertextual reference, linking women's obligation to getting married to Sterne's sentimentalised account of slavery that I discussed in the previous chapter. This form of intertextuality highlights that critiquing patriarchy by equating (white) women's limited agency with that of slaves was already a fairly conventionalised trope by this time (cf. Armstrong 1987; Ferguson 1992). Henry Crawford comments on Maria's lack of high spirits given her prospect of becoming the mistress of Sotherton:

"You have a very smiling scene before you."

"Do you mean literally or figuratively? Literally I conclude. Yes, certainly, the sun shines and the park looks very cheerful. But unluckily that iron gate, 
that ha-ha, give me a feeling of restraint and hardship. I cannot get out, as the starling said." As she spoke, and it was with expression, she walked to the gate; he followed her. "Mr. Rushworth is so long fetching this key!"

"And for the world you would not get out without the key and without Mr. Rushworth's authority and protection, or I think you might with little difficulty pass round the edge of the gate, here, with my assistance; I think it might be done, if you really wished to be more at large, and could allow yourself to think it not prohibited."

"Prohibited! nonsense! I certainly can get out that way and I will. Mr. Rushworth will be here in a moment you know-we shall not be out of sight." (MP 93)

Coleman interprets this reference to Sterne as a comment on "men's illegitimate power over women" and Sir Thomas's tyranny (2009: n.pag.). For sure, in Austen's writing there is an acute awareness of the tension between women's expected behaviour and their growing desire for freedom, a longing that, as the quoting of Sterne's starling underlines, derives to a large degree from their literacy and familiarity with novels. But while Austen's fiction is, obviously, critical towards the pecuniary dependency of women, the starling episode is not a straightforward defence of female agency. Maria is mocked for her attention-seeking inauthenticity. Even Sterne's original reference to slavery, as I have argued, is self-centred and can also already be read as challenging the conventions of sentimentalism. In this episode in Mansfield Park, it is not Fanny's introspection on her (or her cousin's) plight as women on the marriage market, but rather Maria's imprudence and pretentious stance, uttered "with expression", which is presented. Maria fulfils the role of the inauthentic scheming woman who only marries for her own benefit. To begin with, she is quite content with settling on Rushworth:

Being now in her twenty-first year, Maria Bertram was beginning to think matrimony a duty; and as a marriage with Mr. Rushworth would give her the enjoyment of a larger income than her father's, as well as ensure her the house in town, which was now a prime object, it became by the same rule of moral obligation, her evident duty to marry Mr. Rushworth if she could. (MP 37)

But when Henry Crawford speaks highly of her sister Julia, she cannot help feeling dissatisfied with her hasty attachment. Again, while the 
narrator critiques the assumption of women's "duty" and "obligation" to marry for financial gain (cf. Sturrock 2006: 181), the starling is not an image of authentic critique of patriarchal family constellations (in Austen) or of slavery (in Sterne), but a reference to an obsolete sentimentalist wallowing in self-pity that the more prudent Fanny cannot accept. In contrast to Maria then, the constant emotional turmoil and lack of clarity in the narration of her inner thoughts make Fanny the more authentic antisentimental, and by extension modern, character in the logic of the novel. Maria does not express "authentic" emotions that are the hallmark of the new middle-class habitus but feels entrapped and bored and in this way is closer to an aristocratic impetus of wanting to be wooed. She is easily seduced by the more cosmopolitan charm of Mr Crawford and does not want to oblige the conventions of marriage quite yet, especially if this means competing with her sister-and thus the quotation of the starling's "I cannot get out" is, in fact, a misled comparison to slavery, as is already the case in Sterne's text, that highlights pretence rather than true feeling.

Part of Fanny Price's position as one of Austen's supposedly least likeable heroines (cf. Trilling 1954: 11) is precisely her moralising tone when it comes to proper conduct. She feels torn between what is socially expected of her and what she believes to be expedient. In this scene, "Fanny, feeling all this to be wrong, could not help making an effort to prevent it" (MP 93), but her cousin would not hear of it and leaves with Crawford: "Fanny was again left to her solitude, and with no increase of pleasant feelings, for she was sorry for almost all that she had seen and heard, astonished at Miss Bertram, and angry with Mr. Crawford" (MP 93-94). Familial decorum is difficult emotional terrain for the outsider: on the one hand, Fanny feels grateful and wants to please and, on the other, she is often overwhelmed by her own emotional (and religious) demands of morality - her lack of pleasant feeling coinciding with surprise and anger at the indiscretion of those who should be morally more refined than she is. In the Bertram family, the daughters appear spoilt and more interested in a good match or exciting distractions than finding true companionship. Hence, the critique of familial power relations in Mansfield Park is not simply directed at the men; the scheming women (including Lady Bertram and aunt Norris) are as much to blame. The reception of Fanny in the critical debate accordingly ranges from reading her as a "feminist rebel"- "it is this absence of servility that marks her capacity for resistance" (Easton 1998: 481)22 - to a submissive "Christian heroine", as Lionel Trilling famously labelled her (1954: 12, cf. also Folsom and 
Wiltshire 2014: 25-30). Is Austen's Mansfield Park then part of the novel tradition that works towards the "consolidation of authority", as Said claims (1994: 77), or, is she offering resisting feminist viewpoints, as Susan Fraiman has suggested (1995: 816)?

In contrast to her cousins, Fanny tries, first and foremost, to be "true" to her feelings, and if this means repudiating her uncle's plans for her, she will follow her convictions as in her eventual rejection of Crawford. Given Fanny's socially unclear position within the Bertram family, there is initial insecurity about her introduction to society and it is her obliviousness to Henry Crawford's attempts at entertaining her that gradually convince him of trying to seduce her. He wonders, "What is her character?-Is she solemn?-Is she queer?-Is she prudish?” (MP 213). While Fanny's emotional "queerness" only makes her more appealing in his eyes, ${ }^{23}$ his sister Mary desires that he will "not be making her really unhappy" because "she is as good a little creature as ever lived and has a great deal of feeling" (MP 213 ). In contrast to her cousins, who were born into a social standing that prepared them for being courted, and the worldly Crawfords, to whom courtship feels like a competition, Fanny is depicted as actually caring about other people's feelings.

Preparing for her "outing", Fanny would like to wear the amber cross that her brother William gives her as a present but for which he could not afford a matching gold chain. Mary Crawford presses her into wearing a necklace she originally received from Henry. Once more the passage is rife with Fanny's emotional qualms: "She would rather perhaps have been obliged to some other person. But this was an unworthy feeling" (MP 239). This emotional confusion is only enhanced when Edmund also presents her with a necklace. By now Fanny has fallen for Edmund, who, unaware of Fanny's feelings, in turn, is smitten by Mary's kindness. Since Fanny can only join William's cross to Edmund's chain, she solves her dilemma by wearing both necklaces to the ball, which, according to Peter Smith (1994: 220), symbolise the alternatives of sedition and reform. And here yet again, one can draw a figurative connection between white women's status on the marriage market as akin to slavery, as the necklaces have been read as alluding to the chains of the enslaved (cf. Ferguson 1991: 124). In line with this thinking, Fanny has been described as the uncultured other (Ferguson 1991: 123), a "grateful slave" (Ferguson 1991: 124; cf. Boulukos 2008 for a critique of this trope), or simply "a slave" (Johnson 1988: 107; Smith 1994: 207) in the Bertram family. ${ }^{24}$ 
But while Fanny is indeed "bound" to the Bertrams, her relation to Sir Thomas, I would argue, is much more ambivalent than him yielding uncontested patriarchal power over her as a quasi "slaveholder". Fanny expresses fear and awe towards him, and later, when he shows more affection, she feels emotionally confused and overwhelmed yet again. Feminist critics Sandra Gilbert and Susan Gubar identify "the failure of the father" (2000 [1979]: 137) as a recurring theme in Austen's oeuvre, and much of Mansfield Park's plot revolves around challenged paternal authority rather than straightforward control, literally at home and figuratively as colonial rule abroad. The prohibition of the unseemly theatre production and the need to re-establish order in the colonies are thus linked:

It is our contention that the irony clearly emergent in the last chapter renders a false harmony which underscores the dissonance that remains present in the imperial/paternal order as represented in life at Mansfield Park. In part, it is the artificial deus ex machina and summary manner in which Austen closes out her characters that suggests the false harmony. (Bartine and Maguire 2009: 47) 25

As Bartine and Maguire point out regarding the ending, the tonal ambivalence of the entire novel to a large degree rests on the domestication of the free indirect discourse representing Fanny's ambivalent familial feeling into the (endogamic) marriage plot, supplied by narrator summary in the closing remarks to which I will return. This also relates to the supposedly all-overpowering position of the "patriarch" in the text, whose absence is the precondition for the ensuing sexual liberties and familial drama and whose return initiates the restoration of familial order.

To begin with, the male absentee planter is confronted with two entangled geographies of familial disorder in England and the Caribbean, and Ferguson even speculates about a possible sexual transgression of Sir Thomas in Antigua (cf. 1991: 127). ${ }^{26}$ Stewart, too, discusses the two themes, "the patriarch's chronic absenteeism and the woman's dangerous sexuality" (1993: 109), as interlinked threats in the gendered imperial order of the time. ${ }^{27}$ At home, as outlined, Fanny seems to follow a strict moral code and, at least at first, does not question her uncle's authority. The greatest test of Sir Thomas's role as paterfamilias in Mansfield Park is the preparation of a private theatrical production in his absence. The intertextual inclusion of Elizabeth Inchbald's 1798 popular play Lovers' Vows, an adaptation of the German Das Kind der Liebe of 1780 by August von 
Kotzebue, supports this line of argument. In the play, Frederick is a "bastard", who (like Wedderburn) is quite recalcitrant about this status and voices disdain towards his father. He contends, "No-why should I ever know my father, if he is a villain! My heart is satisfied with a mother. [...] I will work all day at the plough, and all the night with my pen". For he is "a dutiful son for the sake of a helpless mother" (Kotzebue 1798: 13). In exact opposition, Fanny, up to this point, is the dutiful niece/"daughter" of an absent uncle/father. Given the delicate subject matter of the drama, both Fanny and Edmund agree that the play is "exceedingly unfit for private representation" (MP 130). Additionally, Edmund objects to Tom's acquaintance Charles Maddox's presence at Mansfield Park because he fears the "excessive intimacy $[\ldots]$, the more than intimacy-the familiarity" (MP 142) of the strange man in the house. The intertext is both present and absent in the novel, as Plasa argues: "Constantly alluded to and anticipated but never staged, Lovers' Vows is simultaneously included and excluded within Mansfield Park" (2000: 48). The spatial and indeed highly gendered ordering of the family mansion is overcast dangerously by the theatrical. By refusing to act herself, Fanny is depicted as holding on to her ideal of moral and affective authenticity that she sees tainted by pretence, even if for the purpose of performance. ${ }^{28}$

Subsequently, the unexpected early return of Sir Thomas marks the reconfiguration of familial order that also leads to a newfound emotionality towards Fanny. ${ }^{29}$ This novel form of familial feeling, however, only adds to Fanny's ongoing emotional confusion and more than anything feels oppressive:

"Why do not I see my little Fanny?" And on perceiving her, came forward with a kindness which astonished and penetrated her, calling her his dear Fanny, kissing her affectionately, and observing with decided pleasure how much she was grown! Fanny knew not how to feel, nor where to look. She was quite oppressed. He had never been so kind, so very kind to her in his life. (MP 165)

The strain from the colonial turmoil is compensated in an emphasis on domestic quiescence. Physically altered-“he was grown thinner and had the burnt, fagged, worn look of fatigue and a hot climate, every tender feeling was increased" (MP 166)—Sir Thomas explains his dislike of acting: 
"That I should be cautious and quick-sighted, and feel many scruples which my children do not feel, is perfectly natural; and equally so that my value for domestic tranquillity, for a home which shuts out noisy pleasures, should much exceed theirs." (MP 173)

Quietness befalls Mansfield Park once the theatrical production is shut down for good and Fanny believes that her uncle only wants "the repose of his own family circle" (MP 182). Stewart (1993: 31) reads this new accent on familial intimacy as affecting both genders in the house now.

However, Sir Thomas can only resort to the domestic home and hearth once he returns from the colonies: his changed physical appearance, his new emotionality, and his wish to talk about Antigua suddenly shape the domestic mood at Mansfield Park. In contrast to his own children, Fanny becomes quite intrigued by the reasons behind these developments, as the central passage on slavery, the mentioned famous "dead silence", which ensues when she asks him about slavery (cf. Said 1994: 96), underlines. To gain a better understanding of this passage, I quote at some length how the conversation between Edmund and Fanny, who summarise the events in the family circle the night before, unfolds. This dialogue is shaped by Fanny's unease about Edmund (still not aware of her feelings for him) repeating some of the compliments that Sir Thomas extended to her the night before.

"The evenings do not appear long to me. I love to hear my uncle talk of the West Indies. I could listen to him for an hour together. It entertains me more than many other things have done-but then I am unlike other people, I dare say." [...]

"Your uncle is disposed to be pleased with you in every respect; and I only wish you would talk to him more.-You are one of those who are too silent in the evening circle."

"But I do talk to him more than I used. I am sure I do. Did not you hear me ask him about the slave trade last night?"

"I did-and was in hopes the question would be followed up by others. It would have pleased your uncle to be inquired of farther."

"And I longed to do it-but there was such a dead silence! And while my cousins were sitting by without speaking a word, or seeming at all interested in the subject, I did not like-I thought it would appear as if I wanted to set myself off at their expense, by shewing a curiosity and pleasure in his information which he must wish his own daughters to feel.” (MP 183-184) 
While Brian Southam argues in "The Silence of the Bertrams" (1995), much like Said, that Fanny addresses a taboo subject, recent commentators are much more hesitant about what the "dead silence" signifies and whose silence this includes: her cousins', her uncle's, both? (cf. Tuite 2000: 104). Ferguson reads the stillness as connected to the slave insurrections that are not supposed to enter this familial narrative, in which "slave subjectivity has to be effaced" (1991: 133)-literally linking the silence in the mansion to the silenced subaltern. In a more cautious attempt to read closer to the text, Boulukos warns that such postcolonial readings might be overdetermined. Instead, he highlights that Fanny is silent because her female cousins shun the topic, her uncle, at least in Edmund's view, would have been pleased "to be inquired of farther". Boulukos thus understands this conversation as showcasing Fanny's modesty (not trying to stand out at the expense of Maria and Julia) and exemplifying a possible ameliorationist position of Sir Thomas as a "progressive" reformer of slaveholding. Boulukos further argues that it is, in fact, Said's contemporary qualms with the literary archive of how to address issues like slavery and imperialism in (high) literary criticism that causes such misplaced emphasis on the silence on slavery. ${ }^{30}$

Austen could reasonably expect her readers to connect it to a very familiarindeed a culturally central-discourse. Said's method, which necessitates "recovering" the repressed presence of slavery and colonialism, depends on denying the familiarity of the slave trade as a topic of discussion. (Boulukos 2006: 365)

In this reasoning, there is no contemporary need for delicacy, as slavery was a widely addressed topic in public and literary discourse in the late eighteenth and early nineteenth century.

Indeed, following abolition, Britain's new imperial role is framed as a moral responsibility in the sense of a "civilising mission". So rather than condemning slavery, it is the absence of proper familial/imperial control, which is supposedly plaguing the West Indian plantation system. ${ }^{31}$ In this understanding, the purportedly enlightened benevolent upper-class absentee planter needs to interfere to stop the uncouth behaviour of their working-class overseers abroad, who are considered the problem by exerting unnecessary force in supervising the enslaved. According to this ameliorationist agenda, the "workforce" would submit willingly in a more humane system. Actually, the imaginary vision of such a form of control 
rested on voluntary procreation and the introduction of forms of respectable West Indian slave marriages - an allegedly "natural way" to compensate for the outlawed trade in human beings (cf. Boulukos 2006: 371). Hence, rather than constructing a binary of for or against slavery, we need to concede that positions which were critical of the inhumanity of the slave trade could still be reconciled with versions of a reformation of the plantation system in the early nineteenth century. Precisely because these subject matters could fit into the narrative of familial uplift, they were entirely plausible as topics of polite conversation.

But the growing financial insecurity from the Caribbean system of slavery also leads to a new interest in imperial expansion into Africa and Asia and the introduction of a new "fantasy of 'free' yet racialized coercive labor" in the reliance on so-called coolies hailing from both China and South Asia (Lowe 2015: 26) that shapes the post-abolition nineteenth century. Again, the familial and the imperial world are intertwined as references to the Navy in Austen's writing highlight. Britain can display naval might regarding rivalries with France, bolstering a novel pro-imperialism and, at the same time, maintain moral superiority through policing of the slave trade. The British Navy also makes up for familial shortcomings in old aristocratic exchanges of women; it offers new forms of class mobility for men of the lesser gentry and even men like William Price. "The navy becomes a true brotherhood, a better source of hospitality and neighborliness than relatives; the nation-state supplies the deficiencies of family and community alike", argues Ruth Perry (1994: 103) with reference to Persuasion (Austen 2003c [1817]). The increasing global entanglements of Britain that led to more class mobility coincide with an emphasis on the ideal of the home and the rise of global consumerism. The prospect of William going to the East Indies in Mansfield Park, after all, first and foremost means a pretty shawl or two for Lady Bertram (cf. MP 282). Clara Tuite explains these broader social changes:

There is a direct correlation between the novel's regime of familial incorporation and retrenchment, and the post-abolition and pre-emancipation imperial regime, which we could refer to as a regime characterized also by the discourse of improvement and of investment. Austen's novel registers or enacts this coincidence between British imperial expansion and the diminution of the aristocratic family [...]. (2000: 100) 
For Tuite, Austen's depiction of the Bertram family embodies the transitions that the landed gentry faced realistically rather than dwell in an idealised image of an aristocratic family.

Generically situated between country-house and domestic novel, everything following the aborted theatricals revolves around securing the right kind of marriages for all protagonists. After Crawford leaves Mansfield Park, first the marriage between disappointed Maria and Rushworth is discussed by Sir Thomas and his daughter in terms that explicitly highlight the tension between happiness and alliance, as this longer excerpt showcases. $\mathrm{He}$

tried to understand her feelings. Little observation there was necessary to tell him that indifference was the most favourable state they could be in. Her behaviour to Mr. Rushworth was careless and cold. She could not, did not like him. Sir Thomas resolved to speak seriously to her. Advantageous as would be the alliance, and long standing and public as was the engagement, her happiness must not be sacrificed to it. Mr. Rushworth had perhaps been accepted on too short an acquaintance, and on knowing him better she was repenting.

With solemn kindness Sir Thomas addressed her; told her his fears, inquired into her wishes, entreated her to be open and sincere, and assured her that every inconvenience should be braved, and the connection entirely given up, if she felt herself unbappy in the prospect of it. He would act for her and release her. [...] She thanked him for his great attention, his paternal kindness, but he was quite mistaken in supposing she had the smallest desire of breaking through her engagement, or was sensible of any change of opinion or inclination since her forming it. She had the highest esteem for Mr. Rushworth's character and disposition, and could not have a doubt of her happiness with him.

Sir Thomas was satisfied; too glad to be satisfied perhaps to urge the matter quite so far as his judgment might have dictated to others. It was an alliance which he could not have relinquished without pain; and thus he reasoned. Mr. Rushworth was young enough to improve. [...] Her feelings probably were not acute; $[\ldots]$ but her comforts might not be less on that account, and if she could dispense with seeing her husband a leading, shining character, there would certainly be everything else in her favour. A welldisposed young woman, who did not marry for love, was in general but the more attached to her own family, and the nearness of Sotherton to Mansfield must naturally hold out the greatest temptation [...]. Such and such like were the reasonings of Sir Thomas - happy to escape the embarrassing evils of a rupture, the wonder, the reflections, the reproach that must attend it, 
happy to secure a marriage which would bring him such an addition of respectability and influence, and very happy to think any thing of his daughter's disposition that was most favourable for the purpose. (MP 186-187, emphasis added)

It is quite interesting to observe in this exchange between father and daughter how the seemingly authentic concern for her happiness, which must not be sacrificed for the sake of alliance, shifts into his happiness; repeated three times as Sir Thomas's gain: he is happy that he does not have to embarrassingly call off the marriage, happy that his relatively low status of a Baronet-in contrast to the well-established aristocratic Rushworths (cf. Steffes 1996: 35-36) —will be elevated by this new connection in the region, and finally, he is happy that he has achieved all of this without having to appear oblivious of his daughter's true feelings. ${ }^{32}$ Mansfield Park challenges the family as the uncontested locus of sexuality, albeit in terms that make Maria's and Henry's behaviour seem reproachful, especially from the point of view of the moral centre, the focalizer Fanny.

With the Bertram sisters leaving Mansfield Park for London following Maria's wedding, Henry Crawford confesses his new plans to marry Fanny Price to his sister Mary. She replies: "Does she know her own happiness?" (MP 270). Fanny's emotional composition is tied repeatedly to her status as an object of exchange between the Bertram and Crawford families and the question of whose happiness counts seems unclear; "she is the very one to make you happy", states Mary (MP 271), while her brother is sure that: "I will make her very happy, Mary, happier than she has ever yet been herself, or ever seen anybody else" (MP 271). But Fanny is only experiencing "utmost confusion of contrary feelings" (MP 278), as the following description of contradictory emotions underlines: "She was feeling, thinking, trembling about everything; - agitated, happy, miserable, infinitely obliged, absolutely angry" (MP 279). Having never expected to be in a situation where she has to reject a suitor, Fanny fights with her troubled rivalling affections for her brother and Edmund as well as her continuous repudiation of the unwanted attention from Henry Crawford. The third book accordingly begins with Fanny's rejection of Crawford, marking her emotional agency.

Initially, Sir Thomas accuses her of being "[s]elf-willed, obstinate, selfish, and ungrateful" (MP 295). Paradoxically, the modern female individual puts her own desires before the familial concerns of lineage and 
reputation here, which, in turn, is interpreted as too much emotionality and immaturity: "I am half inclined to think, Fanny, that you do not quite know your own feelings" (MP 292) and her uncle continues to accuse her of a new form of modern "perverse" wilfulness in young women:

I had thought you peculiarly free from wilfulness of temper, self-conceit, and every tendency to that independence of spirit, which prevails so much in modern days, even in young women, and which in young women is offensive and disgusting beyond all common offence. But you have now shewn me that you can be wilful and perverse [...]. (MP 293)

Fanny's inclusion into the family highlights the conflicted terrain of selfless familial affection as opposed to a charitable project of reform. Makdisi accordingly interprets Mansfield Park as epitomising the shifts from the outdated mode of violent control with regard to slavery in the Caribbean and the family in the domestic sphere to a new form of nineteenth-century self-government, both in imperial and familial terms (2014: 138) and Wood in his reading also emphasises Austen's parodic reference to the concept of "improvement" (2002: 296).

However, while I find the general political shift described by these critics highly plausible, Fanny seems less controlled in her affective reactions. She continuously struggles to fulfil the obligations of sympathy in her role as a progressively independent feeling subject with genuine emotionality. As Festa succinctly puts it, "Fanny Price does not feel as she ought" (2009: 450). Despite her outsider position, she is the only one who is immersed in the happiness of others. Following the departure of the Bertram sisters, Fanny genuinely misses them: "their tender-hearted cousin $[\ldots]$ thought of them, and felt for them, with a degree of affectionate regret which they had never done much to deserve" (MP 189). Boulukos describes this as a form of governmentality of gratitude that was also expected of "grateful slaves". The dependent young woman Fanny, in his reading, "resists heroically" and does not follow "obligations of gratitude" (Boulukos 2008: 26). According to Sara Ahmed's study on Willful Subjects (2014), expressions of will and compliance are closely related to the capacity to resist: "willfulness as a judgment tends to fall on those who are not compelled by the reasoning of others" (2014: 15) and "If will is narratable as freedom (to will freely is to be one's own cause) then freedom is affectively registered as guilt" (2014: 27). In order to become free then, Fanny must resist notions of obligation. ${ }^{33}$ But despite this inclusion of rebellious 
interiority, the ending with its emphasis on endogamy seems to work against Fanny's more genuinely modern "will to feel", which I refer to as the novel's resisting tonality. ${ }^{34}$

Endogamy is interpreted as a satirical strategy to cope with financial losses analogous to the restructuring of the post-abolition plantocracy by Tuite. She describes this as a "combination of critique and satire and instruction in the values of domesticity" (2000: 99) and accentuates that satire nevertheless includes elements of conservative restoration (2000: 102). Read as a more traditional "country-house novel" (2000: 96) Mansfield Park displays an interest in the policing of family, the incest taboo, as well as the exclusion of the upwardly mobile Crawfords. The final pairing of Fanny and her cousin Edmund, with whom she grew up like a brother after all, as well as her enchantment with her naval brother William, highlight the levelling of Fanny's aspirations for emotional modernity into an incestuous ${ }^{35}$ version of "little England" in the end. ${ }^{36}$

Nevertheless, before coming to a resolution, Fanny returns to her original family in Portsmouth once more. There she quickly realises that everything is uncomfortable; her old home is too small, her family too uncouth, the place too loud and not as civilised as Mansfield Park. Fraiman (1995: 810) interprets this as two opposing forms of familial violence: what in Mansfield is silence, is noise in Portsmouth. Dunn too, emphasises that Fanny's unbelonging to both worlds can be seen as a reason for her emotional ambivalence: "since the flaws of most of the members of both families place severe limits on the types of emotional bonds which she is able to establish with them, she must do her duty and aspire to emotions that should ideally accompany such performance" (1995: 493). Fanny, on the one hand, like Wedderburn, has to voice her wilfulness to become a modern subject, but, at the same time, this can only be successful within the confines of the familiar. Her comfort at Mansfield finally counts—she cannot be married off against her will, and Sir Thomas too eventually prizes "domestic felicity" (MP 437) over pecuniary ambitions. Despite the initial disappointment, he now orders the fire to be lit in her room every day. This concession to female agency, in turn, is somewhat hastily brushed over in the "happy ending" of the novel that unites Fanny and Edmund. ${ }^{37}$

The eventual mutual affective attachment they develop for each other is only very briefly commented on in the last chapter which opens with the narrator emphasising, "My Fanny [...] must have been happy in spite of every thing. She must have been a happy creature in spite of all that she 
felt or thought she felt" (MP 428). The narrator affectionately lays claim to the protagonist as "my Fanny" and, at the same time, the narrative discourse suddenly cannot access the principal focalizer's emotional register: there is no free indirect thought anymore explaining Fanny's emotions. Quite the opposite, the narrator proclaims happiness despite the lack of representation of "all that she felt or thought she felt". With regard to this passage, Judith Burdan directs "our attention once again to Austen's use of irony, to those insistent 'musts' that punctuate her narrative and train our ears to hear the 'opposites' that lie within them" (2001: 203). The section reads:

I purposely abstain from dates on this occasion, that every one may be at liberty to fix their own, aware that the cure of unconquerable passions, and the transfer of unchanging attachments, must vary much as to time in different people.- I only entreat every body to believe that exactly at the time when it was quite natural that it should be so, and not a week earlier, Edmund did cease to care about Miss Crawford, and became as anxious to marry Fanny, as Fanny herself could desire. (MP 436)

This narrator summary no longer leaves room for the confused emotional introspection of the heroine but gives precedence to the queer temporality of heterosexuality, ${ }^{38}$ "the time when it was quite natural that it should be so", which shapes the Victorian ideal of domesticity in the further establishment of the domestic novel in the years to come. In how far this should be framed as parodic, as Claudia Johnson would have it, who speaks of the "unwontedly Sternean garrulity" (1988: 114) of the narrator, is not entirely clear (cf. also Voskuil 2014: 611). For Trilling, "Jane Austen's irony is only secondarily a matter of tone. Primarily it is a method of comprehension" (1954: 9). Her novel depicts, probably for the first time, a degree of female emotional ambivalence, that, while not letting go of the ideal of the family altogether, makes it more self-reflexive than before. "Fanny's inner life, her power to interrogate her own feelings, is one reason, perhaps the reason, she is the heroine" (Brown 2014: 117). Mansfield Park offers resisting tonalities precisely because of the incongruity between an ultimately conservative narrative voice and the supposed authenticity of the focalizer's agitated mixed emotions. 


\section{Wilful Familiarity: Robert WedDERbURN'S THE HORRORS OF SLAVERT}

Born in Jamaica as the son of a Scottish planter and an enslaved woman named Rosanna, Robert Wedderburn came to England a free man in 1778 (HoS 66) or 1779 (HoS 45) and became a Unitarian preacher. Editor Iain McCalman calls Wedderburn a "tavern orator, debater and singer, as well as a radical preacher and performer" (HoS 5). In contrast to more prominent early transatlantic writers, such as self-educated and highly respectable Olaudah Equiano, who traces his lineage to an African dignitary, or Ignatius Sancho and his aspirational Black family life in London as a free man of letters, Wedderburn does not hide the fact that he was once imprisoned for blasphemous libel. Furthermore, Wedderburn's insistence on his "unrespectable" familial background makes for an uncomfortable reading experience: "It is this unrespectability or roughness which distinguishes Wedderburn so decisively from his predecessors" (HoS 5), writes McCalman in his introduction to The Horrors of Slavery. The short abolitionist autobiography and somewhat obscure political pamphlet published in 1824, which Thomas calls "both life writing and jeremiad" (S. Thomas 2014b: 99), remains his most famous piece of writing.

Focusing on an exchange of letters between Wedderburn and a Miss Campbell that was printed in The Axe Laid to the Root, a periodical that Wedderburn published himself in the wake of his involvement with "Thomas Spence's circle of ex-Jacobin revolutionaries and agrarians in 1813" (McCalman in HoS 12; cf. also McCalman 1993), Linebaugh and Rediker read Wedderburn as "a theorist of the Atlantic proletariat" (2000: $313),{ }^{39}$ indebted to the biblical idea of Jubilee. ${ }^{40}$ However, in this publication as well as in letters Wedderburn repeatedly invents fictional addressees - for example a supposed editor of said journal. The exchange with this alleged half-sister Miss Campbell, whose existence historians Linebaugh and Rediker accept as factual, is now more widely questioned (cf. Morris 2011; S. Thomas 2014a: 510-511). ${ }^{41}$ Both McCalman and Morris interpret this as Wedderburn's attempts to "give the impression of a community of correspondents" (Morris 2011: n.pag.). Writing is used here not only to claim individuality; it is employed strategically to evoke a community of solidarity-even if it is an invented one. Once more, we see that early Black Atlantic writing needs to be situated in more ambivalent aesthetic and political contexts than simply discern the supposed radicalness of these first published texts by Black authors. The literariness of 
Wedderburn is not so much a question of style, which is often characterised as oral given his practice as a public speaker, but of understanding writing as a direct tool in the call for action, disregarding the distinction of fact and fiction as well as the demands of literary originality. ${ }^{42}$ Wedderburn's prose is probably the least polished and therefore might also sit less easily within my entangled account of how the British novel rose to generic fame but I do believe that his text quite uniquely uses notions of wilful familiarity that are based in nineteenth-century novelistic conventions as well as imagine a newly inclusive transnational audience that goes beyond eighteenth-century transatlantic writing and that can and indeed should be understood as a Black male counterweight to the white female introspection that Austen presents.

Hence, rather than engage in the enquiry into the historical accuracy of Wedderburn's possibly invented voices, which Sue Thomas has unfurled quite helpfully (2014a), I will focus on the Horrors of Slavery as a wayward literary text that moves further away from sentimentalism and challenges conventions of familial feeling by plagiarising well-established abolitionist discourse and claiming a new form of mixed-race subjectivity in writing. Following from the cautionary remarks in the introduction regarding a binary rather than entangled perspective on canonical and marginalised authors, I believe we have to resist a premature romanticisation of political radicalness in this endeavour. The notion of entanglement highlights that neat boundaries between Austen's supposed conservatism as opposed to Wedderburn's radicalness will only get us this far. So rather than focus too narrowly on the autobiographical, Wedderburn's text should also be treated as literature. Like Austen's Mansfield Park, The Horrors of Slavery is no longer simply sentimental in tone, but in contrast to the more famous domestic novel, it does not embrace the ideal of reform which is to become central to Victorian conceptions of familial care. While Austen's heroine Fanny Price dismisses her less respectable Portsmouth working-class family in favour of the more orderly world of the Bertrams, her struggles are depicted as internal only. Wedderburn uses his family history as an exemplum to demand global justice and changes in how the formerly enslaved and colonised should be considered in relation to Britain.

Obviously, such variation in aesthetic choices can be explained by the generic differences between Austen's novelistic discourse and Wedderburn's life writing. But his unconventional narrative is also distinctly different from other Black Atlantic authors whose work is autobiographical as well. Wedderburn's texts, Innes argues, 
illustrate his difference from Equiano, or his later compatriot, Mary Seacole. For whereas these writers are concerned with self-improvement, and with representing the extent of their individual achievement which often involves acceptance in English society, Wedderburn is chiefly concerned with denouncing the injustices not only of slavery, but also of a society where gross poverty and inequality is endemic. (2002: 58)

Even though the pamphlet is dedicated to the most famous British abolitionist of all, William Wilberforce, who visited Wedderburn in prison and encouraged him to publish his story, ${ }^{43}$ Wedderburn does not emphasise Englishness and affective bonds with his fellow Christians, as the more common sentimental abolitionist discourse would. Wedderburn combines sentimental pathos with a new, unrespectable and resisting tone. This emphasis on being a social failure and his resistance to narratives of selfimprovement, as McCalman notes (in HoS 4) (cf. also Pencek 2014: 63), could be read as a truly anti-social queer move of embracing failure avant la lettre. The text opens with conventional sentimental strategies of abolitionist writing by attributing the eponymous "horrors of slavery" to white cruelty (cf. Bernier 2007: 73). This is almost always linked to the disregard of familial bonds - the selling of children and the concomitant mother's suffering and so on, all common tropes aimed at humanising enslaved people of African descent. But Wedderburn's family narrative is unabashedly recalcitrant. So, on the one hand, The Horrors of Slavery is surely the most overtly political intervention into British hegemony from a Black perspective at the time. On the other hand, there is longing for the family that is also quite unique.

Looking back at his life the more than sixty-year-old Wedderburn states at the outset of his account: "To my unfortunate origin I must attribute all my miseries and misfortunes" (HoS 44). Accordingly, Eric Pencek calls this an "autobiographical denunciation of his father" (2014: 61). ${ }^{44}$ Through his unapologetic acknowledgement of interracial sexualised violence, Wedderburn's text repudiates idealised family conceptions and shows the intimate entanglements between the Caribbean and Britain. The source of stigma here is not his Black but specifically his white heritage. Wedderburn begins straightforwardly:

I must explain at the outset of this history-what will appear unnatural to some-the reason of my abhorrence and indignation at the conduct of my father. From him I have received no benefit in the world. By him my mother 
was made the object of his brutal lust, then insulted, abused, and abandoned; and, within a few weeks from the present time, a younger and more fortunate brother of mine, the aforesaid A. Colville [sic], Esq. has had the insolence to revile her memory in the most abusive language, and to stigmatise her for that which was owing to the deep and dark iniquity of my father. Can I contain myself at this? or, have I not the feelings of human nature within my breast? (HoS 45)

His seemingly "unnatural" disavowal of his father is rooted in the inhumanity of treating his mother as his property (cf. HoS 47). This family heritage is complicated by reversing colour-coded and racialised hierarchies, describing his Black mother's stigma as an effect of his white father's moral lapse, his "dark iniquity". It is precisely Wedderburn's capacity to feel like any other human being that torments the son of an "abandoned" mother who still wishes to establish bonds with his white father, continuously claiming the status as "brother" of A. Colvile, his white half-brother who denounces these familial ties. The true "horror" of Wedderburn's writing then is not slavery in the literal sense, which he never experienced first-hand (cf. Morris 2011: n.pag.; H. Thomas 2000: 269; S. Thomas 2014a), but his familiarity with both his father's abuse and his mother's suffering. Convicted for blasphemy, connected to radicals and pornographers, Wedderburn is not a compliant sentimental figure on whom easy sympathy can be bestowed, although he, like other abolitionists before him, claims humanity via the capacity to feel. His published testimony, in the 1820s we have to remember still quite exceptional for a Black writer, is an important means to claim subject status, "to say what I am, and who were the authors of my existence" (HoS 44). He is testifying to how he was written into his unfortunate circumstances, the product of several competing scripts it seems, among them his conversion to Christianity ${ }^{45}$ and political radicalism seem intimately intertwined with his family history. Accordingly, Helen Thomas argues that Wedderburn "portrays himself as a Christ-like but militantly radical saviour who must reject and disobey his earthly father" (2000: 261). He endorses "the paradigm of the mulatto as a radical agent of socioeconomic transformation" (2000: 262). However, this alleged "radical agent" continues to seek approval from his hostile paternal family.

Can we thus establish a connection between the unruly tone of his polyphonic pamphlet to his racial positionality, to what Thomas calls the "paradigm of the mulatto" and what I would term a wilful text? Again, I 
want to frame the resistances of Wedderburn as somewhat more ambivalent than simply equate his writing (or racialised positionality) with political radicalness. While Equiano and Sancho have only little connection to their African parentage, Wedderburn and Seacole both have white Scottish fathers and Jamaican mothers. For Seacole, this heritage turns her into the ideal ambassador for the British empire, as I will argue in the following chapter, for Wedderburn the intrafamilial violence is the beginning of his life-long misery. Consequently, rather than read him in the context of postcolonial hybridity (cf. Bhabha 1994), my emphasis on wilfulness, which was connected to a kind of female perversion in Austen, is meant here to highlight the violent perverse material aspects of sexualised violence that inform the affective mode of the narrative.

The ubiquitous rhetorical sentimental question, "Hath not a slave feelings?" (HoS 47), is dutifully quoted (or plagiarised one could argue) by Wedderburn to explain and defend his mother's rebellious temper. Wedderburn states in full: "Hath not a slave feelings? If you starve them, will they not die? If you wrong them, will they not revenge? Insulted on one hand, and degraded on the other, was it likely that my poor mother could practise the Christian virtue of humility, when her Christian master provoked her to wrath?" (HoS 47-48). But more than the abolitionist claim to feeling, Innes reads this passage as an adaptation of Shylock's famous speech in Shakespeare's The Merchant of Venice (III.l) (cf. Innes 2002: 57).

The religious difference of Jew versus Cristian is transferred by Wedderburn to the juxtaposition of enslaved versus free Christian. Shylock's monologue reads:

[...] I am a Jew. Hath not a Jew eyes? Hath not a Jew hands, organs, dimensions, senses, affections, passions [...]? If you prick us do we not bleed? If you tickle us do we not laugh? If you poison us do we not die? And if you wrong us shall we not revenge? If we are like you in the rest, we will resemble you in that. If a Jew wrong a Christian, what is his humility? Revenge. If a Christian wrong a Jew, what should his sufferance be by Christian example? Why, revenge. ([1596] in Shakespeare 1998: 438)

Aleida Assmann (2015: 177-180) characterises this scene as inherently ambivalent: On the one hand, it is supposed to evince shared humanity and seeks to trigger empathy-which, Assmann argues, presupposes the sharing of feeling with an Other (here "the Jew") in contrast to sympathy 
that is built on similarity-but quickly tilts into the threat of revenge of the "vindictive Jew", essentialising difference as a boundary that cannot be overcome by physical similarities. Christian and Jew, in Shakespeare, and master and slave, in Wedderburn, are similar in their physical wants, their bodies' capabilities more alike than different in their need for nourishment, but still these similarities are violently overlooked. Departing from the abolitionist familiar formula, "Am I Not a Man, and A Brother?", Wedderburn's mother is granted similarity (in feeling) but a new (or in fact older, less acquiescent Shakespearean) form of agency that implies revolt. Accordingly, Wedderburn's appeal to sameness must be read not as a call for white benevolence, but rather as the origin of Black anger and revolutionary threat. "If you wrong them, will they not revenge?" Slavery is not a pitiful spectacle that white sentimentalism can bemoan as a distant past; it still threatens Britain's contemporary social peace, which Wedderburn's references to bloodshed in Haiti only underline. His text in this way also addresses a transatlantic audience and does not simply cater to a supposedly empathic and progressive British abolitionist elite. This is striking because the fear of such incendiary rhetoric (language that via affective power translates into direct action) in the context of the terror of revolution (both exemplified by the events in France 1789 and Haiti 1791-1804 during his lifetime) was often seen as contributing to a backlash against the early abolitionist campaign headed by Wilberforce whose bills to abolish the slave trade were rejected repeatedly in the early $1790 \mathrm{~s}$ and one reason why the abolitionist movement only succeeded once the political climate had become calmer in 1807 eventually.

Sometimes, Wedderburn rhetorically denounces violence and states that he is fearful of "the prospect of a general rebellion and massacre" (HoS 61) in the West Indies. At other times, he proclaims that an uprising will be the result of continued support for the plantation economy, and thus, he more than other Black authors evokes Black agency in overthrowing the system of enslavement for good. ${ }^{46}$ In the first edition of The Axe Laid to the Root from 1817, he writes, "Oh, ye oppressed, use no violence to your oppressors, convince the world you are rational beings, follow not the example of St. Domingo, [...] leave revengeful practices for European kings and ministers." And he encourages them instead to stage a sort of sleep-in of appearing one hour late to their labours arguing that, "The universality of your sleeping and non-resistance, will strike terror to your oppressors" (in HoS 81). Wedderburn simultaneously claims the moral high ground by not succumbing to the vile practices of "European kings 
and ministers" and implicitly threatens the "oppressors" with the terror that awaits them. Wedderburn pleads with the enslaved not to engage in direct violence but have faith in divine intervention on their behalf. Accordingly, Bernier argues that Wedderburn "translates the visceral to the imaginary by allowing their feelings of rage and anger to be expressed in symbolic and immediate literary language purposefully designed to incite the passions of their audience in favour of black emancipation" (2007: 74). Wedderburn evokes an (imaginary) entangled audience both in Britain and the Caribbean, including planters and enslaved, white men and women as well as people of colour. ${ }^{47}$

Moreover, in recounting his life story Wedderburn continuously inverts expectations. Whereas in the colonialist racist logic, it is the climate and the licentiousness of the "native" women that leads white colonisers astray, the visibility of interracial offspring in the colonies and increasingly also in the metropole challenges familial and familiar British narratives. It is not the overt sexuality of the Black woman that corrupts his father, but the morally damaging effects of money, especially if used in dealing in human beings. "While my dear and honoured father was poor, he was chaste as any Scotchman, whose poverty made him virtuous; but the moment he became rich, he gave loose to his carnal appetites" (HoS 46). Honest working Scotchmen are exculpated from carnal sins and the detested father can be envisioned as once "dear and honoured", epitaphs he repeatedly uses strategically to address both his father and his assumed brother. Wedderburn continues his account by juxtaposing his father's lacking education ("[m]y father's mental powers were none of the brightest") with his mother's abilities, who "had received an education which perfectly qualified her to conduct a household in the most agreeable manner" (HoS 46). The appraisal of his mother continues: his father gave him freedom, so he never had to endure slavery, but he cherishes his mother's insubordinate temper: "I glory in her rebellious disposition, [...] which I have inherited from her" (HoS 59). Talkee Amy, his maternal grandmother, too, is described as heroically stubborn. The perversion of the plantation system is the simultaneous familiarity and lack of familial affection which becomes more than obvious when Wedderburn recounts how a young man flogs his grandmother, a woman who "had brought up this young villain from eight years of age, and, till now, he had treated her as a mother" (HoS 49). The sexual and familial intimacy of the plantation for a long time was considered safely separate from the ordered domesticity in Britain, with Mansfield Park a case in point. Nevertheless, as Wedderburn's 
story shows, scruples about enslaving their own children seem to have persuaded more and more slave owners to grant their offspring freedom, probably unsuspecting that they could or would cross the Atlantic to claim a part in the family.

This increasing visibility and in Wedderburn's case literary articulation of mixed-race offspring is one of the most striking signs of the global entanglements of British familial feeling. This form of tabooed genealogy impacts people of African descent to this very day. In her momentous auto-ethnographic study Lose Your Mother Saidiya Hartman critically interrogates the contemporary African American affective desire to frame the history of slavery as one of severed familial bonds, with the dead white patriarchs still haunting this lineage to this day:

Who fails to recognize the figures, the planter and the concubine, the other tragic couple of the New World romance, a romance not of exalted fathers but of defiling ones? Who hasn't heard it all before? The story of murky adulterated bloodlines, rapacious masters, derelict fathers, and violated mothers. Bastaard was what the Dutch called their mixed-race brood; the term implied an illegitimate child as well as a mongrel. If these dead white fathers could speak, no doubt they would be hard-pressed to allow "son" or "daughter" to pass through their lips. Yet these ghostly patriarchs commanded more attention than anyone else in our battered line, if only because they could be named. (2008: 77-78)

In The Horrors of Slavery, the discrepancy between Wedderburn's father's brutality and his mother's suffering functions as a wedge into the sentimentalised rhetoric of family. Literally, he is not the "man and brother" but the more horrific "bastard offspring" who does not claim simply abstract human dignity via emotionality but actual familiarity. But in contrast to the lost family ties that Hartman describes, Wedderburn can actually reconstruct his matrilineal and patrilineal heritage and he even seems to indulge a certain pride in the violent undertones of his white Scottish ancestry as much as in his Black maternal resilience. He claims his Scottish lineage via his last name from his father James Wedderburn, Esq. of Inveresk near Musselborough (1730-1807). James Wedderburn was the third child of Sir John Wedderburn, fifth Baronet of Blackness (1704-1746), who had embraced the cause of the exiled House of Stuart and fought at Culloden. Because of his involvement in the Jacobite Rebellion, John Wedderburn was executed in 
November 1746 and the Baronetcy of Wedderburn was forfeited. Subsequently, James Wedderburn, like other family members, made his fortune in Jamaica as a sugar planter. ${ }^{48}$ He returned to Scotland in 1773 where he assumed the name of Wedderburn Colvile ${ }^{49}$ in 1807. Hence his son, Wedderburn's presumable half-brother, is called Andrew Colvile (1779-1856/1865?). ${ }^{50}$ Wedderburn's father thus is no nameless "ghostly patriarch".

On entering England for the first time in 1779, Wedderburn even speculates about his Scottish rebel grandfather:

My grandfather was a staunch Jacobite, and exerted himself strenuously in the cause of the Pretender, in the rebellion of the year 1745. For his aiding to restore the exiled family to the throne of England, he was tried, condemned, and executed. He was hung by the neck till he was dead; his head was then cut off, and his body was divided into four quarters. ${ }^{51}$ When I first came to England, in the year 1779, I remember seeing the remains of a rebel's skull which had been affixed over Temple Bar; but I never yet could fully ascertain whether it was my dear grandfather's skull, or not. (HoS 45)

Wedderburn from time to time distances himself from the atrocities of his slave-owning Scottish ancestors and, simultaneously, seems to want to be included in this rebellious Scottish tribe, repeatedly speaking fondly of his "dear" grandfather (who most certainly would not have accepted him as kin) and his "dear father" who did give him freedom after all. Linking Scottish and Jamaican histories, the Wedderburn family exemplifies how the political turmoil on the British Isles had concrete global effects with Jamaica becoming an exile and way to uphold family incomes for the time being until a return of the Jacobite offspring seemed feasible.

It is the literal familial connection (including the monetary implications), which Wedderburn demands, entering a dispute with his Scottish family about his inclusion into the Wedderburn clan. To do so publicly, as Wedderburn did, was an unheard-of affront that the half-brother tries to stop by threatening him with legal action. Ending up poor in Britain, Wedderburn had sought financial support from A. Colvile, calling him an "affectionate brother, who refused to relieve me" (HoS 60). Once Wedderburn publishes his account, Colvile contests Wedderburn's parentage as contrived (HoS 53) and adamantly maintains that his father never had "any connection of that kind with the mother of this man" (HoS 52, original emphasis). Wedderburn in turn disputes his white half-brother's attempts to exonerate their father while simultaneously claiming a share in 
the profits from his sugar plantation-a paradoxical demand for an antislavery campaigner it would seem (cf. Morris 2011). Their correspondence as well as the letters of the editors of Bell's Life in London are included in The Horrors of Slavery.

The intermediary voice of the editors clearly sides with Wedderburn's account. Polemically now, the abolitionist slogan (as well as another reference to Shakespeare, this time to Hamlet) recurs and is tested when it comes to blood relations, as Wedderburn and Colvile's correspondence is framed by the mocking, "BROTHER OR NO BROTHER-'THAT IS THE QUESTION?"” (HoS 5l). The editors even argue that as a gesture of reconciliation it is precisely the acceptance of such offspring into the realm of the familial that could be the beginning of healing the wounds that were caused when "the dearest ties of consanguinity are trampled upon by a sordid thirst of interest". They call for an inclusion of the "bastard" into the family, "an offspring that should be the more closely cemented by the ties of affection, [...] let, then, the bonds of sympathy lighten the bondage to which they were (however unjustly) born" (HoS 55 ). Quite radically then here the interracial family is imagined as a locus of affective reconciliation in the aftermath of slavery. To a certain degree this framing of interracial identity also reoccurs in Britain's emphasis on mixed families in contemporary national memorial culture that I will discuss in the conclusion. So, while Equiano hardly ever mentions his white wife and petitions for a return to Africa, Sancho establishes a respectable Black family of Sanchonettas and Seacole later refutes all allusions to possible sexual relations with white men, The Horrors of Slavery calls for the acceptance of interracial families, using the vocabulary of familial belonging. Wedderburn naturalises the idea of parenthood in light of violence against Black women. ${ }^{52}$ The editors of Bell's Life in London even dare to ask of this alleged brother to imagine what it might feel like had his white mother endured the same fate (cf. HoS 57).

While Mansfield Park demonstrates that slavery has, in fact, become a topic of polite conversation in early nineteenth-century Britain, the tone of address seems tenuous. Part of this tenuousness, I believe, has to do with the slowly increasing visibility of mixed-race offspring like Wedderburn that showcases the lack of moral superiority that is supposedly attached to whiteness. Publishing his pamphlet, addressing audiences as a public speaker, but also in his letters to his half-brother, Wedderburn's familial discourse is affecting and disrupting the colonial separation that British families sought to uphold for as long as possible. In Mansfield Park, the 
colonies are an abstract and distant realm of familial obligations and no character from the West Indies ever becomes a speaking subject, in Ahmed's terms a "willful subject", in the hushed discourse on slavery. Wedderburn in contrast tries to make his familial story public.

However, as with all Black writing of the period, not only the familial lineage but also authorship, as mentioned, remains complicated regarding, for instance, the questionable literacy and a possible amanuensis of Wedderburn (cf. Pencek 2014: 63; S. Thomas 2014b: 100). Pencek emphasises the oral style of The Horrors of Slavery (cf. 2014: 66) and argues, "Wedderburn not only appropriates wholesale other texts into his own, but also (probably) invents other voices with which to enter into dialogue" (2014: 68). Can one hence align not only his mixed-race heritage but also his disputed authorial qualities with what I have called the wilful resisting tone of Wedderburn's writing? Wedderburn can be interpreted as a revolutionary modern Black individual or the voice of the masses depending on whether one reads his text as an expression of individual style as an author and storyteller or decodes his narrative simply as an intertextual convolute. Pencek, like Linebaugh and Rediker earlier, clearly favours a reading of Wedderburn as challenging modern conceptions of individuality. He writes: "However memorable the individual Wedderburn may be, in polemical action, his voice becomes the voice, not of a revolutionary, but of the revolution. His anonymity is intolerable because it threatens fundamental assumptions of personal individuality" (Pencek 2014: 74). In terms of the literary voice this seems plausible. However, if we look at the affective politics of the text, it is the very specific family history of Wedderburn that seems to lend The Horrors of Slavery moral weight and pushes the text in the direction of (individualised) testimony. Wedderburn's polyphonic account includes standard tropes of sentimentality but moves them in a different, unrespectable direction.

The Horrors of Slavery is neither an autobiography, nor a collection of letters. Contrary to Equiano's neatly distributed Interesting Narrative, complete with prominent subscribers list, Wedderburn's pamphlet is a messier source to consider: It cannot be linked straightforwardly to sentimentalism or abolitionist tract. ${ }^{53}$ The original title page of the text, typeset in a variety of fonts and sizes, which in and of itself is not too remarkable at the time, ${ }^{54}$ illustrates the strange generic mix. This text includes the abolitionist tract, "The Horrors of Slavery" exemplified in "the life and history" of the Reverend Robert Wedderburn whose imprisonment in His 
Majesty's Goal at Dorchester is boldly advertised, his correspondence to his brother and finally, "remarks on, and illustrations of the treatment of the blacks, and a view of their degraded state, and the disgusting licentiousness of the planters" (HoS 43) (Fig. 4.1).

Comparing this title, for instance, to late eighteenth-century sources like Ottobah Cugoano's Thoughts and Sentiments on the Evil and Wicked Traffic of the Slavery and Commerce of the Human Species, Humbly Submitted to the Inhabitants of Great-Britain, by Ottobah Cugoano, a Native of Africa (1999 [1787]) $)^{55}$ and Equiano's The Interesting Narrative of the Life of Olaudah Equiano, or Gustavus Vassa, the African, Written by Himself (2003 [1789]), Wedderburn's text appears more ambiguous. His "life and history" no longer follows eighteenth-century conventionalised accounts of slavery that humbly (and sentimentally) petition on behalf of the "poor Africans". It demonstrates a more outrageous familiarity with his father and brother, who are identified by name and address. Wedderburn is not an exceptional African; he is the West Indian son of a "Slave-Dealer" and a rebellious preacher who is "disgusted" by the behaviour of the planters, including his father. Hence, the polite detached discourse on abolition is transformed into a more uncomfortable familiarity.

Intervening into the separate spheres of home versus colony, Wedderburn's account is certainly not novelistic in style but can still be regarded in conjunction with the more domestic narratives of its time. His text, which is much more entangled with the transatlantic sphere than Austen's world of little England, becomes an essential counterweight to the assumed silence not on slavery but of the (formerly) enslaved. In postcolonial and feminist criticism, it is not enough to state the symbolical analogies between enslaved people and women. Entanglement here also means to complicate such notions from an intersectional perspective that does not neatly separate gender and race as exclusive categories and that should be understood as a heuristic device to provide a transnational lens on the rise of the British novel. In such an understanding, entanglement becomes a counterweight to the idea that counterpoint is only a retrospective possibility of interpretation. Thus, as laid out in the beginning of the book, by speaking of entangled tonalities I subsume several different ways of relating two sources in the individual chapters. Sometimes, they share a certain sensibility in relation to familial feeling (the foundational tone of modernity in Defoe and Equiano, the digressive mode of Sterne and Sancho's letters that amounts to direct intertextuality and later the humorous and intrusive consolidating tone of Seacole and Dickens's narrators). 


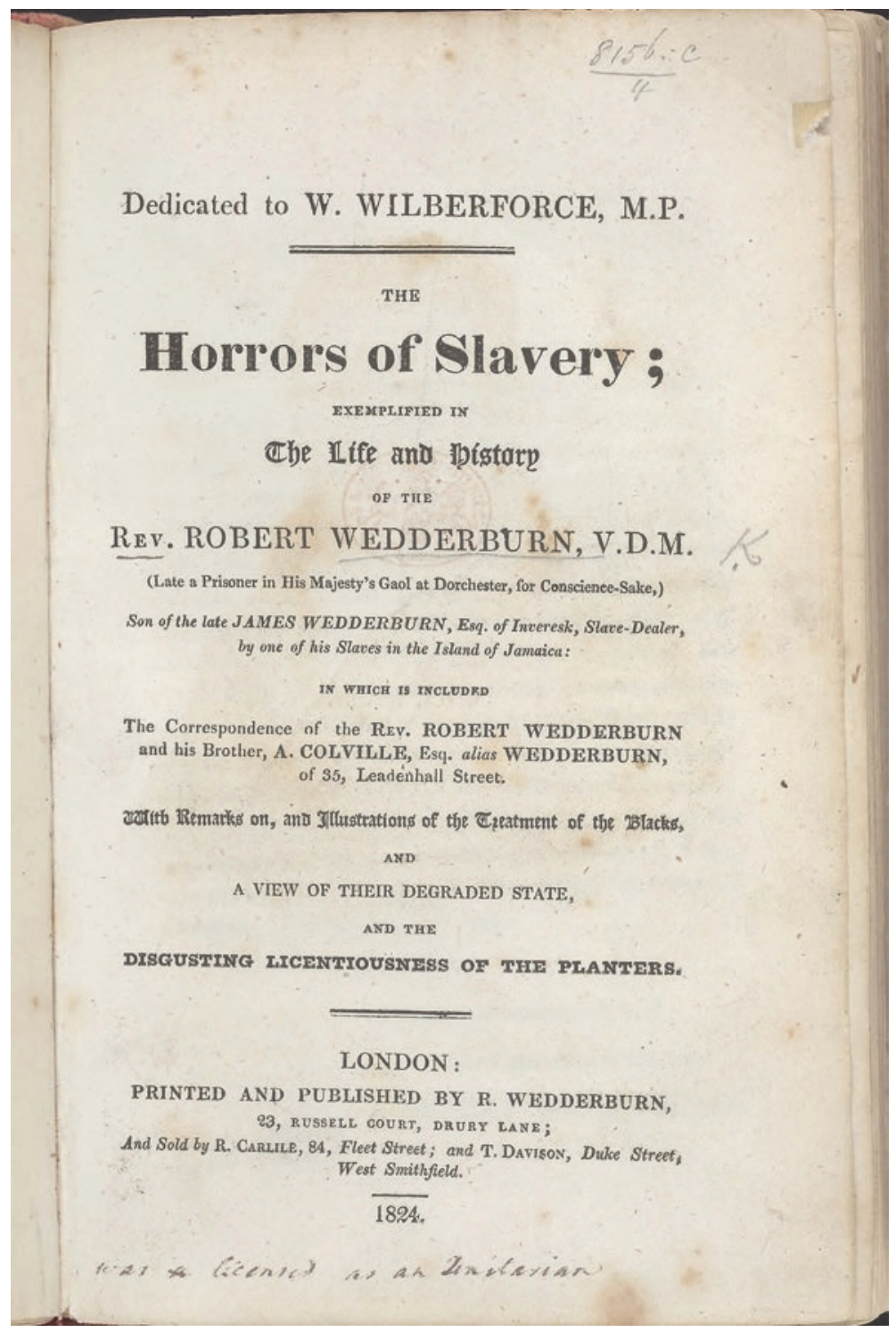

Fig. 4.1 Title Page of Robert Wedderburn's The Horrors of Slavery (London, 1824) 
In the case of Austen and Wedderburn the connection might appear less obvious. Juxtaposing and bringing into conversation the voices of an unlikely (and potentially unlikeable) white female heroine and a Black male preacher, however, demonstrate that a certain wilful resistance to modes of familial feeling opened new (entangled) tonalities in British prose writing.

Both the Horrors of Slavery and Mansfield Park deal with resisting family decorum in order to claim subject status. Robert Wedderburn and Fanny Price can be framed as wilful subjects in relation to familial feeling that thus is denaturalised. Despite different generic and aesthetic registers, the pamphlet of Wedderburn and Austen's artful novel can be joined as resisting romanticised notions of familiarity as well as a straightforward binary of radicalness versus complicity in favour of ambivalence: The illicit offspring of a slave and a planter fights for his place in the Scottish family, the "ungrateful" poor relation resists being appropriated into the marriage market but also finds a place in the family. Each in their own way, while they might not please contemporary readers' affective desire for a feminist heroine or a Black infallible revolutionary, Austen's and Wedderburn's texts contribute to an entangled expanding literary representation of familial feeling in the nineteenth century.

\section{Notes}

1. In the following, quotes from the two primary sources Mansfield Park (Austen 2003a [1814]) and The Horrors of Slavery (Wedderburn 1991 [1824]) will be abbreviated as MP and HoS respectively in all in-text citations.

2. Additionally, the ongoing military conflict with France in the Napoleonic Wars made a reassessment of Britain's imperial role necessary (cf. Capitani 2002; Tuite 2000: 99-100).

3. Lowe speaks of "the British shift from eighteenth-century mercantilism and colonial slavery toward the new forms of empire that enabled the global expansion of trade in manufactured goods in the nineteenth century" (2015: 69).

4. In contrast to Raymond Williams who speaks of Austen's remarkable "unity of tone" (2016 [1973]: 165, 166), I wish to highlight the contradictions between the tone of the narrator and character-focalizer.

5. In her 1957 introduction to Mansfield Park, Queenie Dorothy Leavis, for example, links the plot to the years 1808-1809 (reprinted in Leavis 1983); cf. also Kathryn Sutherland's introduction (in MP xxx); Folsom and 
Wiltshire (2014: 5); Lloyd (1999); Southam (1995). Gabrielle White (2006: 30-31) summarises various critics' attempts to assemble a logical internal chronology which they base on the fact that the ball on 22 December takes place on a Thursday and the mention of a following late Easter. These efforts turn out to be relatively futile when trying to match these dates to the references made in the novel to The Quarterly Review (only begun in 1809) and another publication of 1812. Hence, while the text invests in a realistic timeline, it becomes nearly impossible to state an exact date other than equating the ending roughly with the present of its contemporary readers.

6. Mansfield Park is widely praised for its realistic psychological insights. The book was, for instance, famously described as "the first modern novel in England" by Q.D. Leavis who reads it as foreshadowing the accomplishments of acclaimed novelists George Eliot and Henry James (1983: 167).

7. Mrs Price's family situation is characterised in the following terms in the text: "A large and still increasing family, an husband disabled for active service, but not the less equal to company and good liquor, and a very small income to supply their wants, made her eager to regain the friends she had so carelessly sacrificed" (MP 6).

8. Said states in full: "everything we know about Austen and her values is at odds with the cruelty of slavery" and later: "It would be silly to expect Jane Austen to treat slavery with anything like the passion of an abolitionist or a newly liberated slave. Yet what I have called the rhetoric of blame, so often now employed by subaltern, minority, or disadvantaged voices, attacks her, and others like her, retrospectively, for being white, privileged, insensitive, complicit. Yes, Austen belonged to a slave-owning society, but do we therefore jettison her novels as so many trivial exercises in aesthetic frumpery? Not at all, I would argue, if we take seriously our intellectual and interpretative vocation [...]" (1994: 96).

9. What is more, Wiley critiques postcolonial approaches, in general, and Said, in particular, for focusing too narrowly on the question of representation of the subaltern/native (2014: 64).

10. Wood interprets Austen's evasive references to slavery on the Antiguan plantation even as a conscious reaction to an oversaturated public discourse following the high time of abolitionist and pro-slavery comment predating 1807 , reading the silence as possibly resulting from "boredom and overexposure" (2002: 300). While I find this intriguing, I am, for reasons that are hopefully apparent in my reading, less convinced that Austen can be seen solely as a social satirist of the abolitionist fervour.

11. Jon Mee, for instance, speaks of Austen's “female patriotism” (2000: 80) as a shielding against French radicalism. 
12. Fraiman (1995: 809), for example, assigns Austen political outsider status on account of her sex as a female author, which Said only accredits to Joseph Conrad due to his Polish heritage (cf. also Wiley 2014). Fraiman discusses the gendered logic of scandalising "gentle Jane's" connection to slavery in the manifold varied critical reactions to Said's reading. She accuses Said of a cursory reading of the text, including misidentifying Maria Bertram as "Lydia" at one point (cf. Said 1994: 87) and not paying the same attention to the oeuvre of the author as he does to the texts of the male authors he analyses in Culture and Imperialism (Fraiman 1995: 807-808). In the meantime, her own reading has become subject to multiple critical interrogations. Coleman (2009) accuses her of wrongfully attributing the analogy between the "governess-trade" and the slave trade to Jane Fairfax rather than Mrs Elton in Emma. The widely cited passage in Emma begins with Jane Fairfax admitting that she would seek employment as a governess, phrasing it awkwardly: "There are places in town, offices, where inquiry would soon produce something-Offices for the sale—not quite of human flesh—but of human intellect'." To which Mrs Elton replies agitatedly: “'Oh! my dear, human flesh! You quite shock me; if you mean a fling at the slave-trade, I assure you Mr. Suckling was always rather a friend to the abolition.' 'I did not mean, I was not thinking of the slave-trade,' replied Jane; 'governess-trade, I assure you, was all that I had in view; widely different certainly as to the guilt of those who carry it on; but as to the greater misery of the victims, I do not know where it lies'” (Austen 2003b [1815]: 279-280). While it is true that the formulation of the "slave-trade" is only used by Mrs Elton, Jane Fairfax's wording "not quite human flesh" does seem to evoke a similarity to slavery at the very least. This is underlined by the fact that Jane Fairfax, while conscious of the greater guilt in the slave trade, even speculates whether slaves or governesses suffer a more pitiful fate. Here, more explicitly even than in Mansfield Park, women's financially precarious situation is seen as analogous to that of (often conspicuously "ungendered") slaves, whose capacity to even register misery is construed as only roughly equal to that of refined cultured women who are forced to take on a supposedly demeaning profession.

13. Tuite (2000: 94) helpfully situates the liberal-feminist response to Said's reading within a larger rift between a more traditional philological understanding of English literary studies and post-/Marxist and postcolonial critique that place different emphasis on text versus context. Cf. also Perry (1994: 100): "Because Said is unable to imagine the dependent status of women, despite his use of terms like 'gender' and 'feminism', he does not notice that in all the late novels colonialism is associated with women."

14. Said's reading was published first in a 1989 essay collection before its revised inclusion in Culture and Imperialism in 1993. 
15. White's Jane Austen in the Context of Abolition (2006) to date provides the most detailed overview of historical texts and possible sources that Austen might have consulted.

16. The following critics link Austen's naming of Mansfield Park to Lord Mansfield: Ferguson (1991: 130); Kirkham (1997: 116-117); Lew (1994: 273); Plasa (2000: 34); Steffes (1996: 30); Stewart (1993: 120); White (2006: 5-6); Wiley (2014: 61). Wiltshire (2003: 306) for one finds a reference to the character of Lady Mansfield in Richardson's Sir Charles Grandison (1972 [1753]), which Austen admired, more plausible.

17. Cf. also Moreland Perkins's essay (2005) in which he reads Mansfield Park as an extended analogy of Clarkson's text.

18. Soon Wiley, too, emphasises the violence that is attached not only to the colonial, but also to the domestic sphere: "What Said sees as order, tranquillity and beauty in Mansfield Park, I would call tyranny, cruelness and excessive wealth" (2014: 67).

19. Trevor Lloyd (1999) makes this point by disentangling the family finances is some detail. Fowler (2017), in turn, argues that Said, in fact, underestimates the importance of country houses' colonial connections.

20. I believe Wiltshire's emphasis on postcolonial "obvious misreadings" (2003: 316) — and his entirely misplaced use of the term "decolonising" to describe his attempt to unfetter Austen criticism from such supposedly misguided ideologues-betrays a longing for a restoration of an unambiguous authoritative literary criticism predating any poststructuralist uncertainty, especially should this form of criticism espouse feminist or postcolonial standpoints. Obviously, there is much to be debated about earlier interpretations of the novel, including that of Said, which is what many postcolonial scholars, including myself, do. However, accusing postcolonial criticism in toto of trying to fill the blanks in literary texts, in effect, negates the work of literary interpretation to begin with. Even more problematically, in his joint introduction with co-editor Marcia McClintock Folsom for the 2014 Approaches to Teaching Austen's Mansfield Park, part of the widely used MLA Approaches to Teaching World Literature series, and despite the admitted necessary inclusion of three articles dealing with the abolitionist context of the novel, their biased view is phrased as a moral call to revert the attention from slavery to more pedagogically suitable topics: "Another question that teachers must weigh is, What other political and social concerns of the novel are displaced or distorted by bringing slavery and the slave trade to the fore of interpretation?" (Folsom and Wiltshire 2014: 33). Again, the authors seem to be implying that it is somehow unrighteous (and pedagogically dangerous?) of teachers of literature to focus on marginalised aspects of a work of fiction since this must necessarily amount to "distortion". 
21. Alicia Kerfoot resists a purely metaphorical linking of slavery and women's status in the economy of exchange in her discussion of the biopolitical implications of marriage laws and legislation on slavery reading them as "the same questions of habeas corpus as the Hardwicke Marriage Act of 1753 and the Mansfield decision of 1772" (2008: 277). While it is true that legally white women still lack a lot of the basic rights that slaves want too-they are legally bound to fathers and husbands-this framing still does not acknowledge the intersectional problems of simply equating race with gender. This framework does not take into consideration the gender of enslaved men and women who are excluded in multiple and conflicting ways in the economy of exchange that Kerfoot describes.

22. Easton's linking of Fanny to both England's working class and the Black Atlantic proletariat, including references to Robert Wedderburn, remains vague: "In the end, the Mansfield property lines that even Mary and Henry uphold are altered by Fanny, whose Portsmouth perspective unites plebian English and black Atlantic values against the modern superintendents of plebian life, whether they are from London or Northamptonshire" (1998: 482).

23. Admittedly, Henry Crawford's ambition is first and foremost "making a small hole in Fanny Price's heart" (MP 212).

24. Mee writes: "In Mansfield Park, black slavery functions, like Fanny's gold chain, as a metaphor for female enslavement in Sir Thomas's household" (2000: 85); Carl Plasa similarly argues that Fanny figures "as the slave(s) for who she is herself a kind of living metaphor" (2000: 53). Allen Dunn (1995: 491) frames this more cautiously as service with regard to Fanny's lower-class background: "Fanny's humility and self-mastery make her a willing servant to her aunts, and a dutiful ward and sometimes a dutiful daughter." He also emphasises the lack of feeling between the class-segregated families of Fanny in Portsmouth and Mansfield Park and reads this as one explanation for Fanny's constant emotional indecisiveness (cf. 1995: 495). The analogy between gender and race is also increasingly shifted to an analogy of class and race with descriptions of the "Black" working classes in later Victorian writing (cf. Easton 1998 and the following chapter on Dickens and Seacole).

25. Despite Bartine's and Maguire's insightful discussion of tonal ambivalence, they somewhat problematically conflate the narrator's comment and author intention in their overall judgement of the novel.

26. Despite the lack of direct textual evidence in Mansfield Park, Ferguson understands the growing number of free people of colour in the Caribbean as a possible reference point. The much-discussed 1999 British film adaptation written and directed by Patricia Rozema makes this subtext explicit. Critics like Sturrock (2006) and Wiltshire (2003) see this as fundamentally 
flawed and unfaithful to the original source, while others, like, Bartine and Maguire (2010), grant the filmmakers more artistic licence in their interpretation of the text.

27. This, in turn, links the novel to Wedderburn's text, which addresses sexual intemperance of British men in the Caribbean (only alluded to in Austen) much more explicitly. What is more, in an article on two newly discovered letters by Austen's brother Charles, who served in the Royal Navy, Ruth Knezevich and Devoney Looser (2015) speculate about the effects of Charles Austen's familiarity with two mixed-race free women in Barbados who are described as hoteliers and explicitly associated with prostitution. This is an additional connection to Mary Seacole's narrative, who continuously tries to proclaim her distance from such a form of catering to the sexual needs of British seafarers and soldiers. The colonial space is imagined time and again as one of sexual transgressions, in which white men are led astray by (overly sexualised) Caribbean women.

28. Festa understands this as "Fanny's refusal to alienate herself, either through the theatrical assumption of another character or through the marketing of the self in marriage" (2009: 436).

29. Wiley also emphasises this novel interest in family upon Sir Thomas's return: "He exhibits more sympathy and tenderness towards Fanny. He also expresses genuine interest in enjoying his familial life and role as a father" (2014: 70).

30. Makdisi speaks of a conflation of slavery and imperialism in Said (2014: 134).

31. Cf. Steffes (1996) who discusses the Austen family's own involvement in plantation slavery.

32. Joanna Aroutian (2006: 231) discusses this in relation to Foucault's wellknown framing of the emergence of modern sexuality as a shift from the deployment of alliance to the deployment of sexuality which has been outlined in the introduction in greater detail. Consequently, she reads Maria's eventual divorce resulting from her later elopement with Crawford as the ultimate rebellion.

33. In relation to Sir Thomas's pushing for Fanny's marriage to Crawford, Jon Mee argues, "genuine family feeling has too often been sacrificed to an ossified sense of duty" (2000: 78). While Mee links Fanny's sincere feeling to her patriotic love of the English countryside, I want to emphasise the disorientation in her emotional responses that shapes the narrative discourse of the novel.

34. Hence, while Makdisi emphasises the similarities in which colonial subjects and women in the domestic sphere were increasingly exposed to a "civilising mission" that posited an "Occidentalist discourse of governmentality" (2014: 144) in which internalised self-regulation is the key to a new form 
of enlightened liberty, I would caution not to conflate the regulating final narrator summary with the much more ambiguous focalization of the character throughout the story. It seems to me that even though the entanglement of domestic and colonial sphere is immediately plausible, there is a moment of affective distinction at work. The increasingly well-read women in Britain exhibit a form of emotionality that both exemplifies refinement and requires control. This, as Austen's female heroines show, is also hallmark of the novel form and its pleasurable consumption. This affective individuality to a large degree is then still a marker of distinction that privileges both whiteness and femininity. Before self-regulation is achieved, the novel offers ample room to ponder different outcomes.

35. Aroutian argues, "Her brother's presence complicates Fanny's potentially sexual relations by reminding her of her duties toward family via the incest taboo" (2006: 235). In contrast, Kirkham reads this as a critique of the enlightenment ideals of fraternity which need to be established not only between siblings but also between spouses (1997: 119; cf. also Johnson 1988: 117). In a somewhat problematic analogy of "intrafamilial and interracial transgressions", Plasa reads the "inscriptions of incest in Austen's novel" to "assume new meaning: just as the slave is a figurative or metaphorical brother, so the incestuous desire for a literal/biological brother comes to constitute a trope for miscegenation" (2000: 54). This figurative reading of "miscegenation" ignores the actual familial bonds that increasingly extend into the Caribbean as will be argued with regard to Wedderburn and overlooks the more complicated intersections between race and gender.

36. Coleman (2009) also reads this as an enclosing of the familiar in light of colonial expansion and Easton argues, "The bodily fear of external 'infection' $[\ldots]$ and the xenophobic sense of others as 'foreign' [...] —as well as the often noticed endogamy of the novel-are as much about the defence of a property line as a blood line" (1998: 469).

37. Stewart interprets this as a "triumph of the familiar over the alien in a novel that touches so much foreign material" (1993: 127).

38. Focusing on queer temporalities, critics, such as Halberstam (2005), Freeman (2010), and Love (2007), interrogate "straight time" which is reliant on the linearity of a life narrative as maturing, marriage, and procreation, which many queer lives cannot or do not want to adhere to. In this light, Austen's novel is, of course, a prime example of "straight temporality". However, by calling this the "queer temporality of heterosexuality" I want to highlight the artificial work that the temporal closure of the happy ending performs here. In a novel that zooms in on the feeling of the character-focalizer in long scenes to suddenly summarise supposedly natu- 
ral developments, using only a fraction of discourse time, can come across as quite queer indeed.

39. Gilroy links Wedderburn's radicalism to his profession as a sailor and the crossing of oceans as an important impulse to challenge national identities (cf. 1993: 12-13).

40. Linebaugh and Rediker explain Jubilee as follows: "A plan for liberation, jubilee appeared both in the Old Testament, as a legal practice of land redistribution, and in the New Testament, as part of the fulfillment of a prophecy in Isaiah. The concept comprised six elements. First, jubilee happened every fifty years. Second, it restored land to its original owners. Third, it canceled debt. Fourth, it freed slaves and bond servants. Fifth, it was a year of fallow. Sixth, it was a year of no work" (2000: 290).

41. The conspicuously unannotated popular biographical publication The Axe Laid to the Root. The Story of Robert Wedderburn by Martin Hoyles (2004) also does not challenge the veracity of the supposed (half-) sister and, given its lack of proper documentation, seems a highly speculative source to reconstruct Wedderburn's life story.

42. It is not even entirely clear whether Wedderburn wrote the texts down himself or, due to a lack of command of writing, dictated his texts.

43. Aravamudan (1999: 269) speculates that one of the unnamed texts that Wedderburn received as a gift from Wilberforce might have been Equiano's Interesting Narrative.

44. S. Thomas reads this as a direct reference to Equiano's opening paragraph (2014b: 111).

45. McCalman highlights the specific attractiveness of Methodism in this context, because it incorporated still popular magical and pagan-Christian beliefs, which were also prevalent among West Indian communities of colour at the time (1993: 56).

46. Wedderburn time and again adopts the voice of reason, even citing Wilberforce, but, simultaneously, the image of revolt as a consequence of "disappointed hope" is evoked in a plea for amelioration before complete emancipation: "But although we have said we would never cease to exclaim against the horrible traffic in human flesh until there was an amelioration of the condition of Slavery; yet, unjust as is the argument of force against the force of argument, we wished not an instantaneous emancipation, although we could have wished our Ministers to have gone farther than they have done, and extended their object to the other Colonies, as they have already commenced it in Trinidad. However, as it is, we rejoice to find that there is a beginning to soften the rigour of captivity and fetters; but, as Mr. Wilberforce truly observed, the consequence of disappointed hope might be to drive the Negroes to 'take the cause into their own hands.' With him, we trust that such may not be the case!” (HoS 57). 
47. Discussing a recently discovered anti-abolitionist tract that calls for the compensation of slaveholders which Wedderburn published towards the end of his life, Ryan Hanley cautions against a too narrow understanding of Wedderburn as a political radical, placing this text in the generally complicated debate over authorial authenticity of publications in nineteenthcentury radical circles. Thus, Hanley argues, "His adoption of a number of authorial perspectives, tonalities and even characters complicates any reading of his work that seeks to understand it as uncomplicatedly representative of a static political or ethical perspective" (2016: 427). While I will not engage with this new-found source here, I believe that my reading adds to this more ambivalent interpretation of Wedderburn's life and writing that, I argue, is shaped too by his ambivalent familial feelings.

48. James Wedderburn's older brother, Sir John Wedderburn of Ballendean, 6th Baronet of Blackness (1729-1803) (the title was restored eventually), presumably Robert Wedderburn's uncle, was also a prominent landowner in Jamaica. He became famous in his own right when he lost in the Wedderburn versus Knight case of 1778 in which the enslaved Joseph Knight, whom he had brought to Scotland on his return, wins his freedom. The Knight case is considered a direct reaction to, and the Scottish equivalent of, the earlier English Somerset case. The historical novel Joseph Knight by James Robertson (2003) is a fictional account of Knight's story.

49. Colvile is misspelled as Colville several times in HoS.

50. Colvile would later become Proprietor of Canada's Hudson's Bay Company underlining the continuing British colonial global entanglements that eventually turned towards North America rather than the Caribbean.

51. The brutality of the account of the execution of his grandfather is reminiscent of the climactic self-mutilation of the royal slave Oroonoko in Aphra Behn's eponymous novel.

52. This stands in sharp contrast to the plantation system of the United States: Critiquing the conceptualisation of a supposed matriarchal dominance or matrilineality in African American families as a result of the emasculation of Black men under slavery, Hortense Spillers (1987) challenges more radically whether Black women can be understood as gendered human beings under the auspice of enslavement, since they were reduced to a status of "flesh", which via the partus sequitur ventrem legislation extended to their offspring. Thus, slavery, in Spiller's understanding excluded enslaved people from the very grammar of gender and familial belonging.

53. Alan Rice reads a published letter sent from prison which includes a fierce attack on the monarchy as Wedderburn's "Swiftian satire" (2012: 164). He emphasises that early Black Atlantic writing in general and Wedderburn's texts in particular point to a broader aesthetic vocabulary than the sentimentalism of abolitionism. He argues, "Wedderburn's anarchist vision and 
comic sensibility demonstrate that black voices in the transatlantic literature of this period were not confined to abolitionist discourse. They also drew on the ribald vision exemplified by Swift and graphic satirists like William Hogarth and George and Isaac Cruikshank. A full understanding of African-Atlantic writers and history in this period will require wider reference than the slave narrative which has been sanctioned by the makers of the black canon" (2012: 166). While I do not engage with the more satirical letters here, I similarly want to highlight the "tonal" range of Wedderburn that moves beyond the familiar sentimentalism of abolitionist writing and yet does not entirely let go of the promise of familiarity.

54. Regarding a different letter by Wedderburn, Sue Thomas interprets the use of mixed typography, such as italics, capitalisation, and the usage of exclamation marks, as a form of "emphatic editorialization" that can be linked to the Jamaican oral tradition of "tracing" or "throwing word", a form of personal attack (2014b: 109).

55. The title is altered in an abridged 1791 version, published as Thoughts and Sentiments on the Evil of Slavery; or, the Nature of Servitude as Admitted by the Law of God, Compared to the Modern Slavery of the Africans in the WestIndies; In an Answer to the Advocates for Slavery and Oppression. Addressed to the Sons of Africa, by a Native. The later title also imagines an entangled audience of the advocates of slavery and the "sons of Africa".

\section{Works Cited}

Ahmed, Sara. 2014. Willful Subjects. Durham: Duke University Press.

Aravamudan, Srinivas. 1999. Tropicopolitans. Colonialism and Agency, 1688-1804.

Durham: Duke University Press.

Armstrong, Nancy. 1987. Desire and Domestic Fiction. A Political History of the Novel. New York: Oxford University Press.

Aroutian, Joanna. 2006. The Sexual Family in Mansfield Park. European Romantic Review 17 (2): 229-235.

Assmann, Aleida. 2015. Ähnlichkeit als Performanz. Ein neuer Zugang zu Identitätskonstruktionen und Empathie-Regimen. In Ähnlichkeit. Ein kulturtheoretisches Paradigma, ed. Anil Bhatti and Dorothee Kimmich, 167-185. Konstanz: Konstanz University Press.

Austen, Jane. 2003a [1814]. Mansfield Park. Ed. Kathryn Sutherland. London: Penguin.

- 2003b [1815]. Emma. Ed. Fiona J. Stafford. London: Penguin.

- 2003c [1817]. Persuasion. Ed. Gillian Beer. London: Penguin.

Bartine, David, and Eileen Maguire. 2009. Contrapuntal Critical Readings of Jane Austen's Mansfield Park: Resolving Edward Said's Paradox. Interdisciplinary Literary Studies: A Journal of Criticism and Theory 11 (1): 32-56. 
. 2010. Contrapuntal Critical Reading and Invitations to Invention. Interdisciplinary Literary Studies 11 (2): 38-71.

Bernier, Celeste-Marie. 2007. 'Iron Arguments': Spectacle, Rhetoric and the Slave Body in New England and British Antislavery Oratory. European Journal of American Culture 26 (1): 57-78.

Bhabha, Homi K. 1994. The Location of Culture. London: Routledge.

Boulukos, George. 2006. The Politics of Silence: Mansfield Park and the Amelioration of Slavery. Novel: A Forum on Fiction 39 (3): 361-383.

- 2008. The Grateful Slave. The Emergence of Race in Eighteenth-Century British and American Culture. Cambridge: Cambridge University Press.

Brown, Julia Prewitt. 2014. Questions of Interiority: From Pride and Prejudice to Mansfield Park. In Approaches to Teaching Austen's Mansfield Park, ed. Marcia McClintock Folsom and John Wiltshire, 116-122. New York: The Modern Language Association of America.

Burdan, Judith. 2001. Mansfield Park and the Question of Irony. Persuasions: Journal of the Jane Austen Society of North America 23: 197-204.

Butler, Marilyn. 1987. Jane Austen and the War of Ideas. Reissued with New Introd. Oxford: Clarendon Press.

Capitani, Diane. 2002. Moral Neutrality in Jane Austen's Mansfield Park. Persuasions: The Jane Austen Journal On-Line 23 (1): n.pag.

Clarkson, Thomas. 1808. The History of the Rise, Progress, and Accomplishment of the Abolition of the African Slave-Trade by the British Parliament. London: L. Taylor.

Coleman, Deirdre. 2009. Imagining Sameness and Difference: Domestic and Colonial Sisters in Mansfield Park. In A Companion to Jane Austen, ed. Claudia L. Johnson and Clara Tuite, 292-303. Online edition: n.pag. Chichester: Wiley-Blackwell.

Cugoano, Quobna Ottobah. 1999 [1787]. Thoughts and Sentiments on the Evil of Slavery and Other Writings. Ed. Vincent Carretta. New York: Penguin.

Dunn, Allen. 1995. The Ethics of Mansfield Park: MacIntyre, Said, and Social Context. Soundings: An Interdisciplinary Journal 78 (3-4): 483-500.

Easton, Fraser. 1998. The Political Economy of Mansfield Park: Fanny Price and the Atlantic Working Class. Textual Practice 12 (3): 459-488.

Equiano, Olaudah. 2003 [1789]. The Interesting Narrative and Other Writings. Ed. Vincent Carretta. London: Penguin.

Ferguson, Moira. 1991. Mansfield Park: Slavery, Colonialism, and Gender. The Oxford Literary Review 13 (1-2): 118-139.

- 1992. Subject to Others. British Women Writers and Colonial Slavery, 1670-1834. New York: Routledge.

Festa, Lynn. 2009. Losing One's Place in Mansfield Park. Eighteenth-Century Novel 6-7: 429-463. 
Folsom, Marcia McClintock, and John Wiltshire, eds. 2014. Approaches to Teaching Austen's Mansfield Park. New York: The Modern Language Association of America.

Fowler, Corinne. 2017. Revisiting Mansfield Park: The Critical and Literary Legacies of Edward W. Said's Essay "Jane Austen and Empire" in Culture and Imperialism (1993). The Cambridge Journal of Postcolonial Literary Inquiry 4 (3): 362-381.

Fraiman, Susan. 1995. Jane Austen and Edward Said: Gender, Culture, and Imperialism. Critical Inquiry 21 (4): 805-821.

Freeman, Elizabeth. 2010. Time Binds. Queer Temporalities, Queer Histories. Durham: Duke University Press.

Gilbert, Sandra M., and Susan Gubar. 2000 [1979]. The Madwoman in the Attic. The Woman Writer and the Nineteenth-Century Literary Imagination. New Haven: Yale University Press.

Gilroy, Paul. 1993. The Black Atlantic. Modernity and Double Consciousness. Cambridge: Harvard University Press.

Hanley, Ryan. 2016. A Radical Change of Heart: Robert Wedderburn's Last Word on Slavery. Slavery \& Abolition 37 (2): 423-445.

Halberstam, Judith [Jack]. 2005. In a Queer Time and Place. Transgender Bodies, Subcultural Lives. New York: New York University Press.

Hartman, Saidiya. 2008. Lose Your Mother. A Journey Along the Atlantic Slave Route. New York: Farrar.

Hoyles, Martin. 2004. The Axe Laid to the Root. The Story of Robert Wedderburn. London: Hansib.

Innes, C. Lyn. 2002. A History of Black and Asian Writing in Britain 1700-2000. Cambridge: Cambridge University Press.

Johnson, Claudia L. 1988. Jane Austen. Women, Politics, and the Novel. Chicago: University of Chicago Press.

Kelly, Helena. 2008. Mansfield Park Reconsidered: Pheasant, Game Laws, and the Hidden Critique of Slavery. Persuasions: The Jane Austen Journal 30: 170-180.

Kerfoot, Alicia L. 2008. Replacing the Old Silver Knife: The Convergence of Antislavery Rhetoric and Legal Discourse in Mansfield Park. Journal for Eighteenth-Century Studies 31 (2): 275-292.

Kirkham, Margaret. 1997. Jane Austen, Feminism and Fiction. London: The Athlone Press.

Knezevich, Ruth, and Devoney Looser. 2015. Jane Austen's Afterlife, West Indian Madams, and the Literary Porter Family: Two New Letters from Charles Austen. Modern Philology 112 (3): 554-568.

Kotzebue, August von. 1798. Lovers' Vows. A Play, in Five Acts. Trans. Elizabeth Inchbald. 3rd edition. London: G.G. and J. Robinson. 
Leavis, Queenie Dorothy. 1983. Mansfield Park. In Collected Essays. Volume I: The Englishness of the English Novel, ed. G. Singh, 161-171. Cambridge: Cambridge University Press.

Lew, Joseph. 1994. 'That Abominable Traffic': Mansfield Park and the Dynamics of Slavery. In History, Gender \& Eighteenth-Century Literature, ed. Beth Fowkes Tobin, 271-300. Athens: University of Georgia Press.

Linebaugh, Peter, and Marcus Rediker. 2000. The Many-Headed Hydra. Sailors, Slaves, Commoners, and the Hidden History of the Revolutionary Atlantic. Boston: Beacon Press.

Lloyd, Trevor. 1999. Myths of the Indies: Jane Austen and the British Empire. Comparative Criticism: An Annual Journal 21: 59-78.

Love, Heather. 2007. Feeling Backward. Loss and the Politics of Queer History. Cambridge: Harvard University Press.

Lowe, Lisa. 2015. The Intimacies of Four Continents. Durham: Duke University Press.

Makdisi, Saree. 2014. Making England Western. Occidentalism, Race, and Imperial Culture. Chicago: University of Chicago Press.

McCalman, Iain. 1993. Radical Underworld. Prophets, Revolutionaries and Pornographers in London, 1795-1840. Oxford: Clarendon Press.

Mee, Jon. 2000. Austen's Treacherous Ivory. Female Patriotism, Domestic Ideology and Empire. In The Postcolonial Jane Austen, ed. You-me Park and Rajeswari Sunder Rajan, 74-92. London: Routledge.

Morris, Michael. 2011. Robert Wedderburn: Race, Religion and Revolution. International Socialism 132: online, n.pag.

Pencek, Eric. 2014. Intolerable Anonymity: Robert Wedderburn and the Discourse of Ultra-Radicalism. Nineteenth-Century Contexts 37 (1): 61-77.

Perkins, Moreland. 2005. Mansfield Park and Austen's Reading on Slavery and Imperial Warfare. Persuasions: The Jane Austen Journal On-Line 26 (1): n.pag.

Perry, Ruth. 1994. Austen and Empire: A Thinking Woman's Guide to British Imperialism. Persuasions: Journal of the Jane Austen Society of North America 16: 95-106.

Plasa, Carl. 2000. Textual Politics from Slavery to Postcolonialism. Race and Identification. Basingstoke: Macmillan.

Rice, Alan J. 2012. Ghostly and Vernacular Presences in the Black Atlantic. In Transatlantic Literary Studies, 1660-1830, ed. Eve Tavor Bannet and Susan Manning, 154-168. Cambridge: Cambridge University Press.

Richardson, Samuel. 1972 [1753]. The History of Sir Charles Grandison. Ed. Jocelyn M. Harris. London: Oxford University Press.

Robertson, James. 2003. Joseph Knight. London: Fourth Estate.

Said, Edward W. 1994. Culture and Imperialism. New York: Vintage.

Shakespeare, William. 1998. The Complete Works. Eds. Stanley Wells and Garry Taylor. Compact edition. Oxford: Clarendon Press. 
Smith, Peter. 1994. Mansfield Park and the World Stage. The Cambridge Quarterly XXIII (3): 203-229.

Spillers, Hortense J. 1987. Mama’s Baby, Papa’s Maybe: An American Grammar Book. Diacritics 17 (2): 65-81.

Steffes, Michael. 1996. Slavery and Mansfield Park: The Historical and Biographical Context. English Language Notes 34 (2): 23-41.

Stewart, Maaja A. 1993. Domestic Realities and Imperial Fictions. Jane Austen's Novels in Eighteenth-Century Contexts. Athens: University of Georgia Press.

Sturrock, June. 2006. Money, Morals, and Mansfield Park: The West Indies Revisited. Persuasions: The Jane Austen Journal 28: 176-184.

Southam, Brian. 1995. The Silence of the Bertrams. The Times Literary Supplement February 17 (1995): 13.

Thomas, Helen. 2000. Romanticism and Slave Narratives. Transatlantic Testimonies. Cambridge: Cambridge University Press.

Thomas, Sue. 2014a. Robert Wedderburn's Correspondent Miss Campbell. Notes and Queries 61 (4): 510-514.

- 2014b. Telling West Indian Lives. Life Narrative and the Reform of Plantation Slavery Cultures 1804-1834. New York: Palgrave Macmillan.

Todd, Janet. 1991. Jane Austen, Politics and Sensibility. In Feminist Criticism: Theory and Practice, ed. Susan Sellers, Linda Hutcheon, and Paul Perron, 71-87. New York: University of Toronto Press.

Trilling, Lionel. 1954. In Mansfield Park. Encounter 3 (3): 9-19.

Tuite, Clara. 2000. Domestic Retrenchment and Imperial Expansion: The Property Plots of Mansfield Park. In The Postcolonial Jane Austen, ed. You-me Park and Rajeswari Sunder Rajan, 93-115. London: Routledge.

Voskuil, Lynn. 2014. Sotherton and the Geography of Empire: The Landscapes of Mansfield Park. Studies in Romanticism 53 (4): 591-615.

Wedderburn, Robert. 1991 [1824]. The Horrors of Slavery and Other Writings by Robert Wedderburn. Ed. Iain McCalman: Edinburgh University Press.

White, Gabrielle D.V. 2006. Jane Austen in the Context of Abolition: 'A Fling at the Slave Trade'. New York: Palgrave Macmillan.

Wiley, Soon. 2014. Silence, Slavery, and Jane Austen: Empire in Mansfield Park. Journal of Commonwealth and Postcolonial Studies 2 (1): 59-74.

Williams, Raymond. 2016 [1973]. The Country and the City. New York: Oxford University Press.

Wiltshire, John. 2003. Decolonising Mansfield Park. Essays in Criticism 53 (4): 303-322.

Wood, Marcus. 2002. Slavery, Empathy, and Pornography. Oxford: Oxford University Press. 
Open Access This chapter is licensed under the terms of the Creative Commons Attribution 4.0 International License (http://creativecommons.org/licenses/ by $/ 4.0 /$ ), which permits use, sharing, adaptation, distribution and reproduction in any medium or format, as long as you give appropriate credit to the original author(s) and the source, provide a link to the Creative Commons licence and indicate if changes were made.

The images or other third party material in this chapter are included in the chapter's Creative Commons licence, unless indicated otherwise in a credit line to the material. If material is not included in the chapter's Creative Commons licence and your intended use is not permitted by statutory regulation or exceeds the permitted use, you will need to obtain permission directly from the copyright holder. 